Donohoe, C.; Senge, M. O.; Arnaut, L. G.; Gomes-da-Silva, L. (2019):

Cell death in photodynamic therapy: From oxidative stress to anti-tumor immunity.

Biochimica et Biophysica Acta, Reviews on Cancer 1872, 188308.

doi: 10.1016/j.bbcan.2019.07.003

\title{
Cell death in photodynamic therapy: from oxidative stress to anti-tumor immunity
}

\author{
Claire Donohoe, ${ }^{1,2}$ Mathias O. Senge, ${ }^{2}$ Luís G. Arnaut, ${ }^{1}$ Lígia C. Gomes-da-Silva ${ }^{1 *}$ \\ 1 - CQC, Coimbra Chemistry Center, University of Coimbra, Portugal \\ 2 - Medicinal Chemistry, Trinity Translational Medicine Institute, Trinity Centre for Health Sciences, Trinity \\ College Dublin, The University of Dublin, St. James's Hospital, Dublin 8, Ireland \\ *corresponding author: ligia.cgs@gmail.com
}

\section{Introduction to PDT}

2 Adaptive mechanisms to photooxidative stress

2.1 Integrated stress response

2.2 Antioxidant stress response: The Nrf2 pathway

3 Cell death pathways in PDT

3.1 Accidental Necrosis

3.2 Regulated forms of necrosis

3.3 Apoptosis: intrinsic vs. extrinsic pathways

3.4 Autophagy

4 PDT and immunogenic cell death

4.1 Danger/damage-associated molecular patterns (DAMPs)

4.2 PDT-based vaccines

5 Anti-tumor immunity mediated by PDT

6 Concluding remarks

\begin{abstract}
Photodynamic therapy is a promising approach for cancer treatment that relies on the administration of a photosensitizer followed by tumor illumination. The generated oxidative stress may activate multiple mechanism of cell death which are counteracted by adaptive stress responses that target homeostasis rescue. The present renaissance of PDT was leveraged by the acknowledgment that this therapy has an immediate impact locally, in the illumination volume, but that subsequently it may elicit immune responses with systemic impact. The investigation of the mechanisms of cell death under the oxidative stress of PDT is of paramount importance to understand how the immune system is activated and, ultimately, to make PDT a more appealing/relevant therapeutic option.
\end{abstract}

Keywords: photodynamic therapy, oxidative stress, integrated stress response, endoplasmic reticulum stress, Nrf2 antioxidant pathway, cell death, immunogenic cell death and antitumor immunity. 


\section{Introduction to photodynamic therapy}

PDT has been considered a clinical option for the treatment of solid tumors for the past 25 years. It relies on the administration of a photosensitizer pro-drug which, following a certain time interval, (drug-to-light interval, DLI) is photo-activated by light of a specific wavelength [1]. High DLI facilitates optimal redistribution of the compound in cellular compartments (cellular-PDT). In contrast, low DLI principally targets tumor vasculature (vascular-PDT) [2]. The wavelength selected for PDT typically coincides with the longest-wavelength absorption band of the photosensitizer, ideally occurring between $650-850 \mathrm{~nm}$. This wavelength range corresponds to greatest tissue penetration as well as light of sufficient energy to generate excited states capable of reaction with molecular oxygen. In the presence of oxygen, the photoactivated photosensitizer leads to the formation of reactive oxygen species (ROS) which are highly cytotoxic to the cells where the photosensitizer accumulates (Figure 1). The main ROS generated in PDT are singlet oxygen $\left({ }^{1} \mathrm{O}_{2}\right)$, formed by energy transfer from the triplet state of a photosensitizer (type II). Radical species such as the superoxide ion $\left(\mathrm{O}_{2}{ }^{\circ}\right)$ and hydroxyl radical $\left(\mathrm{OH}^{\circ}\right)$, formed by electron transfer reactions (type I), can also be generated. These ROS are very short lived and react with biomolecules within a micron of their generation site (Figure 1). The anti-tumor effect of PDT is mediated by a combination of three main actions: $a$ ) direct cytotoxic effect on the cancer cells, $b$ ) the destruction of the tumor blood vessels and c) the stimulation of anti-tumor immunity. The latter contributes to the long-term control of the disease and constitutes a major advantage over traditional therapies including surgery or chemotherapy, which are immunologically silent or even immunosuppressive [1,3].

Most of the clinically approved and pre-clinical photosensitizers for anti-cancer PDT are porphyrins, chlorins, bacteriochlorins or phthalocyanines. Porfimer sodium (Photofrin, 'haematoporphyrin derivative'), temoporfin (Foscan, 5,10,15,20-tetrakis(3hydroxyphenyl)chlorin), verteporfin (Visudyne, 'benzoporphyrin derivative') 5aminolevulinic acid (ALA) and talaporfin (Laserphyrin, 'mono-L-aspartyl chlorin e 6 ') are used in clinical practice but demonstrate limited absorptions in the phototherapeutic window, and, by extension, reduced efficacy in the treatment of deep lesions (Table 1). Weeks to months of skin photosensitivity is often observed with some of these photosensitizers. This is due to their low clearance rates resulting in the necessity for periods without sunlight exposure for patients, thus, interfering with their quality of life $[4,5]$.

Table 1. Examples of photosensitizers clinically approved or in clinical trials

\begin{tabular}{|c|c|c|c|c|}
\hline Chemical group & Photosensitzer & $\begin{array}{c}\text { Wavelength } \\
(\mathbf{n m})\end{array}$ & $\begin{array}{c}\text { Approved } \\
\text { applications }\end{array}$ & $\begin{array}{c}\text { Ongoing cancer } \\
\text { clinical trials }\end{array}$ \\
\hline Porphyrin & $\begin{array}{c}\text { Porfimer sodium } \\
\text { (Photofrin) }\end{array}$ & 630 & $\begin{array}{c}\text { Esophageal } \\
\text { and lung } \\
\text { cancer }\end{array}$ & $\begin{array}{c}\text { Bladder, bile } \\
\text { duct, brain and } \\
\text { ovarian }\end{array}$ \\
\hline Chlorin & Temoporfin (Foscan) & 652 & $\begin{array}{c}\text { Lung and skin } \\
\text { cancer }\end{array}$ & $\begin{array}{c}\text { Head and neck } \\
\text { and bile duct }\end{array}$ \\
\hline Chlorin & $\begin{array}{c}\text { Taloporfin } \\
\text { (Laserphyrin) }\end{array}$ & 660 & Lung cancer & $\begin{array}{c}\text { Liver pancreas, } \\
\text { colon and brain }\end{array}$ \\
\hline
\end{tabular}




\begin{tabular}{|c|c|c|c|c|}
\hline Chlorin & Verteporfin (Visudyne) & 690 & $\begin{array}{l}\text { Age Macular } \\
\text { Degeneration }\end{array}$ & $\begin{array}{l}\text { Skin and } \\
\text { pancreas }\end{array}$ \\
\hline $\begin{array}{l}\text { Porphyrin } \\
\text { precursor }\end{array}$ & $\begin{array}{l}\text { 5-aminolevulinic acid, } \\
\text { 5-ALA (Levulan) }\end{array}$ & 635 & $\begin{array}{c}\text { Actinic } \\
\text { keratosis }\end{array}$ & Skin and bladder \\
\hline Bacteriochlorin & $\begin{array}{c}\text { Padeliporfin (WST11, } \\
\text { TOOKAD) }\end{array}$ & 762 & Prostate & \\
\hline Chlorin & $\begin{array}{c}\text { 2-(1-Hexyloxyethyl)-2 } \\
\text { Devinyl } \\
\text { Pyropheophorbide-a, } \\
\text { HPPH (Photochlor) }\end{array}$ & 665 & & $\begin{array}{c}\text { Head and neck, } \\
\text { esophagus and } \\
\text { lung }\end{array}$ \\
\hline Phthalocyanine & $\begin{array}{c}\text { Silicon } \\
\text { phthalocyanine (Pc4) }\end{array}$ & 675 & & $\begin{array}{c}\text { Cutaneous T-cell } \\
\text { lymphoma }\end{array}$ \\
\hline Chlorin & $\begin{array}{c}\text { Chlorine e6 } \\
\text { derivatives (Photolon, } \\
\text { Radachlorin) }\end{array}$ & 660 & & $\begin{array}{c}\text { Nasopharyngeal, } \\
\text { sarcoma and } \\
\text { brain }\end{array}$ \\
\hline Bacteriochlorin & $\begin{array}{c}\text { Redaporfin (LUZ11, } \\
\mathrm{F}_{2} \mathrm{BMet} \text { ) }\end{array}$ & 749 & & Head and neck \\
\hline
\end{tabular}

Some of the limitations of current clinically-approved photosensitizers were partially overcome in the last decade by two photosensitizers based on the bacteriochlorin macrocycle structure: padeliporfin (WST11 or TOOKAD ${ }^{\circledR}$ Soluble) and redaporfin (LUZ11) (Table 1) WST11 is a negatively charged, water-soluble palladium-bacteriochlorophyll photosensitizer prepared from free base extraction from benthic bacteria It exhibits high absorption at 763 $\mathrm{nm}$, low photo-stability and a body clearance within a few minutes $[6,7]$. This rapid elimination limits the risk of skin photosensitivity but requires clinical protocols with infusion administration and simultaneous irradiation. Moreover, protocols with large drugto-light intervals (cellular-PDT), facilitating photosensitizer accumulation at the target cancer cells, are not feasible with WSP11 [8]. Despite this, WST11 phase II clinical trials demonstrated that a vascular protocol $\left(4 \mathrm{mg} / \mathrm{kg}\right.$ and $\left.200 \mathrm{~J} / \mathrm{cm}^{2}\right)$ resulted in $80 \%$ of the patients with negative biopsy at least six months following treatment[9].

Redaporfin (LUZ11, 5,10,15,20-tetrakis( $N$-methyl-2,6-difluoro-3(methylsulfamoyl)phenyl)bacteriochlorin) is a synthetic, amphiphilic bacteriochlorin with an elevated ROS quantum yield, high photo-stability and maximum absorption at $749 \mathrm{~nm}$, which allows for the treatment of relatively deep lesions [10]. Its higher photo-stability, $\left(1^{\text {st }}\right.$ compartment (plasma) half-life of $0.5 \mathrm{~h}$ and $2^{\text {nd }}$ compartment half-life of $65 \mathrm{~h}$ enables the use of redaporfin for both vascular and cellular-PDT [11]. Preclinical studies using a formulation based on Cremophor EL:Ethanol: $\mathrm{NaCl}$ 0.9\% (0.2:1:98.8, v:v:v) demonstrated that different drug-to-light protocols (vascular vs. cellular protocols) resulted in distinct therapeutic outcomes. Vascular protocols attained the best therapeutic outcome for CT26 cells inoculated in BALB/c mice (cure rate around 85\%), S91 melanoma cells inoculated in DBA/2 mice (cure rate $42 \%$ ) and $\mathrm{B} 16 \mathrm{~F} 10$ melanoma cells inoculated in $\mathrm{C} 57 \mathrm{BL} / 6 \mathrm{~J}$ mice (100\% cure rate). This indicated that, at the time of irradiation, the photosensitizer was confined at the blood vessels and tumor destruction was mediated indirectly by starvation and hypoxia [12-14]. Clinical phase I/II trials are currently ongoing (NCT NCT02070432). A recent case report describes the example of a patient with advanced head and neck squamous cell cancer, uncontrolled by surgery, radiotherapy and chemotherapy (cisplatin, carboplatin, paclitaxel, 
cetuximab methotrexate) but obtained remarkable benefit from redaporfin-PDT. Three sessions of vascular-PDT with redaporfin, using the protocol optimized in pre-clinical models, enabled complete visible tumor destruction. Sequential treatment with an immune checkpoint blocker (Nivolumab, PD-1) allowed a complete response with the patient, two years later after the PDT, with no signs of the disease [15].

The therapeutic outcome of PDT is highly dependent on the cellular and molecular mechanism triggered by oxidative damage. The localization of the photosensitizer at the time of irradiation, both in the body and/or cellular compartments, largely determines where oxidative damage will occur due to the short lifetime and limited diffusion ability of ROS [16-18]. Vascular-PDT protocols favor the destruction of the tumor vasculature network and are usually associated with extensive necrosis Cellular-PDT protocols are rather known to have a direct cytotoxic effect on the cancer cells [19]. In the latter case, the intracellular localization of the photosensitizer is a key determining factor. Typically, more hydrophobic photosensitizers accumulate in the membranes of the cellular organelles and can be observed in the endoplasmic reticulum (ER), Golgi apparatus (GA) and/or mitochondria, whilst hydrophilic photosensitizers are more often observed in the endocytic pathway. The pattern of intracellular accumulation has a strong impact on the stress adaption and cell death mechanisms observed. For instance, oxidative damage at the ER/GA and mitochondria is generally deemed the most lethal [16-18]. Finally, a better understanding of the impact of these cellular stress pathways on anti-tumor immunity is critical for the design of new antitumor therapies is critical for the design of new anti-tumor therapies capable of simultaneously killing cancer cells and activating anti-tumor immunity.

The present review highlights the main mechanism of adaptive stress responses and cell death mechanisms prompted by PDT. The contribution of such mechanisms for the high immunogenicity of PDT-killed cancer and thereof, for antitumor immunity, are thoroughly discussed. 


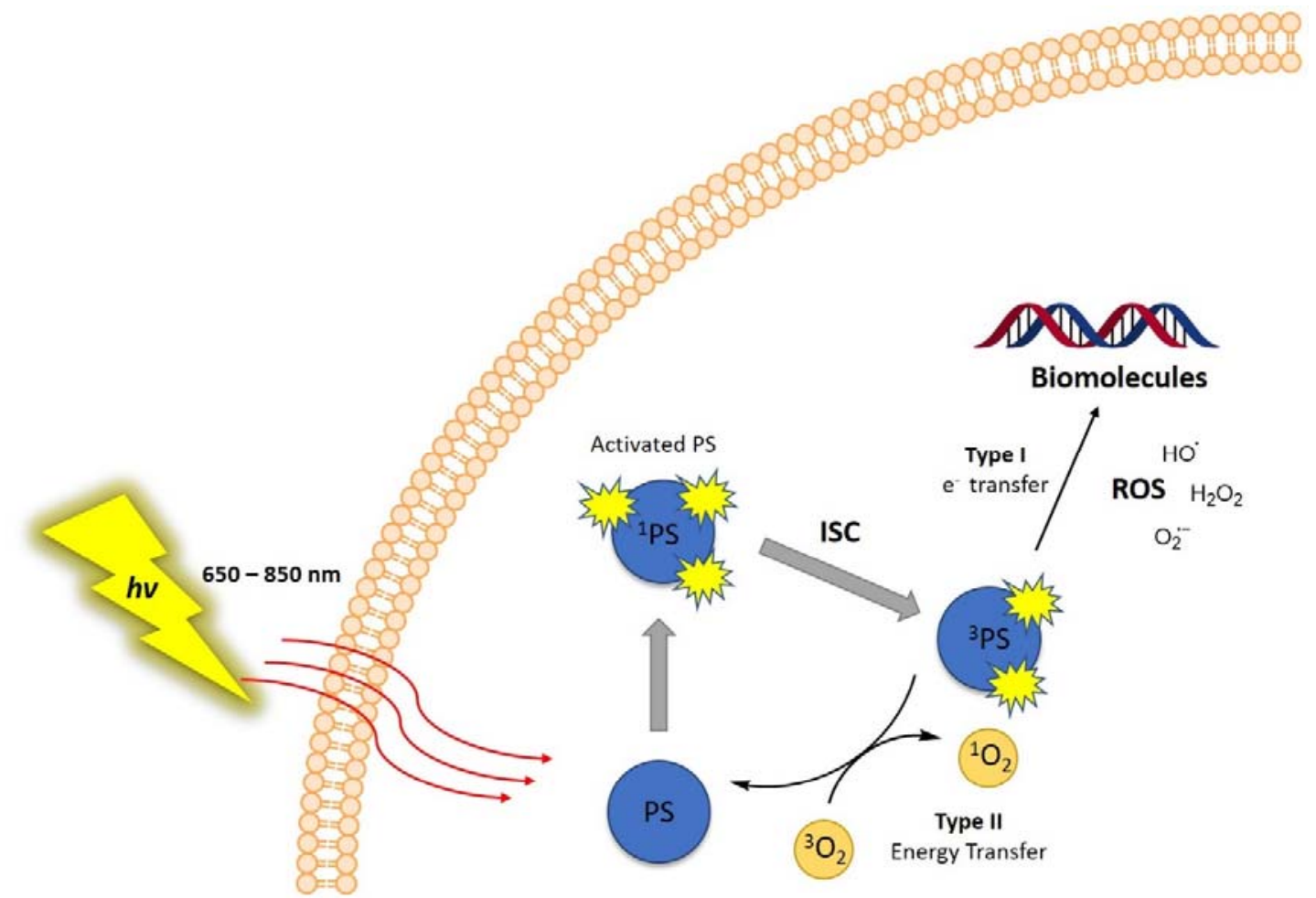

Figure 1. Mechanism of photodynamic therapy.

Type I and type II reactions are initiated when the photosensitizer (PS) absorbs a photon and is electronically excited to the singlet state $\left({ }^{1} \mathrm{PS} *\right)$. The excited PS may undergo intersystem crossing (ISC) to form a relatively long-lived triplet state $\left({ }^{3} \mathrm{PS} *\right)$. In the type I reaction, the ${ }^{3} \mathrm{PS} *$ can transfer an electron to neighboring biomolecules, or directly to oxygen, resulting in radical formation capable of reaction with $\mathrm{O}_{2}$ to produce $\mathrm{O}_{2}{ }^{--}, \mathrm{H}_{2} \mathrm{O}_{2}$ or/and $\mathrm{OH}^{*}$. Alternatively, in a type II reaction, energy of the excited PS may be directly transferred to molecular oxygen, to form singlet oxygen, ${ }^{1} \mathrm{O} 2$.

\section{Adaptive mechanisms to photooxidative stress}

PDT-mediated ROS inflicts damage on different biomolecules, which, depending on the severity may be permanent or repaired. Different adaptive stress responses can be activated upon the oxidative stress experienced by PDT-treated cells as an attempt to remove/ repair damaged material. This ultimately retrieves cellular homeostasis and viability. Typically, these survival mechanisms are regulated by transcription factors including: eukaryotic translation initiation factor 2 subunit alpha (EIF2S1, best known as eIF2 $\alpha$ ) from the integrated stress response (ISR), nuclear factor E2-related factor 2 (NRF2), hypoxiainducible factor (HIF-1), nuclear factor kB (NF-KB) and others (ATF4, XBP1 and ATF6f) from the unfolded protein response (UPR). Overall, these ER stress pathways culminate in a global shutdown of protein synthesis. This halt coincides with various protein chaperons and folding enzymes experiencing increased production, a process regulated by the previously mentioned transcription factors [20] (Figure 2). 


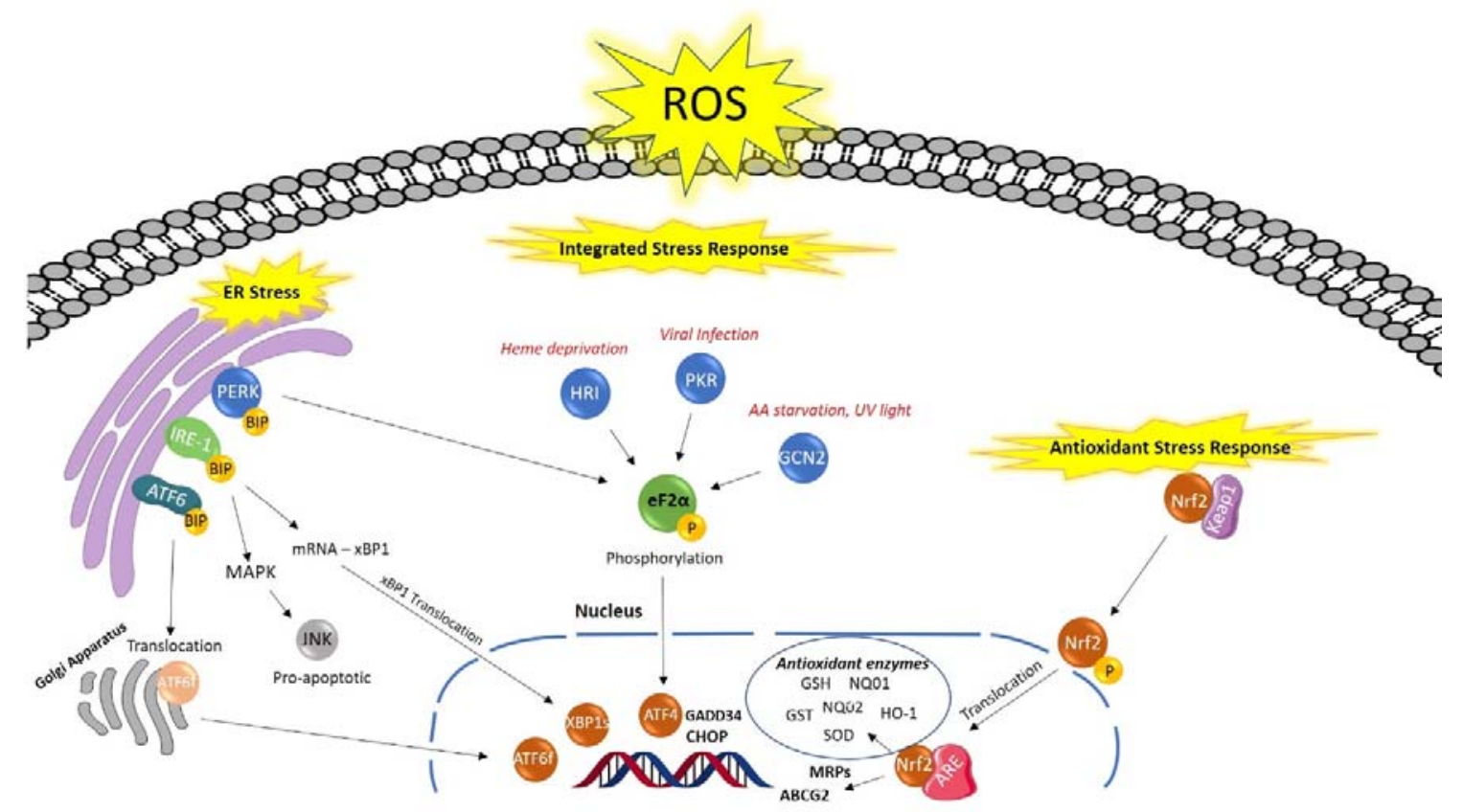

Figure 2 Oxidative stress activates different cell survival pathways.

Distinct types of stress can activate the integrated stress response (ISR), an adaptive pathway that has the phosphorylation of the transcription factor eIF $2 \alpha$, by one of the four eIF $2 \alpha$ kinases (PERK, PKR, HRI and GCN2), as its core event. Accumulation of misfolded proteins is detected at the ER by three sensors, PERK (common to the ISR pathway), IRE-1 or ATF6. Oxidative stress activates the antioxidant stress response mediated by the Nrf2 pathway. Overall, transcription factor activation leads to a decrease in global protein synthesis and the induction of specific genes which together target cellular recovery.

\subsection{Integrated stress response}

ISR is a mechanism common to all eukaryotic cells that responds to different stress conditions through the phosphorylation of eIF2 $\alpha$. Depending on the stress stimulus, eIF2 $\alpha$ phosphorylation may experience mediation by one of the eIF $2 \alpha$ kinases, namely: PKR-like kinase, PERK (ER stress - accumulation of unfolded proteins), double-stranded RNAdependent protein kinase, PKR (viral infections), heme-regulated kinase, HRI (heme deprivation) and general control nonderepressible 2, GCN2 (amino acid starvation and UV light). General protein synthesis is reduced upon eIF2 $\alpha$ phosphorylation. However, specific genes, particularly the transcription factor ATF4, are activated to mediate the expression of genes that attempt to restore cellular homeostasis. When the latter is achieved, eIF $2 \alpha$ dephosphorylation is mediated by the protein phosphatase 1 complex (PP1) and normal protein synthesis is restored [21].

Accumulation of misfolded protein in cells is detected by the ER (ER stress), which activates several intracellular signal transduction pathways, collectively termed the 'unfolded protein response' (UPR). This mechanism has three main stress sensors: protein kinase RNA-like ER kinase (PERK), activating transcription factor 6 (ATF6) and inositol-requiring element1 (IRE-1), as illustrated in Figure 2. Eachare ER transmembrane proteins, generally 
inactivated by direct association to the binding immunoglobulin protein (Bip, best known as glucose regulated protein (GRP78)). Dissociation of Bip occurs when unfolded proteins are accumulated in the ER lumen. PERK phosphorylates eIF2 $\alpha$, which subsequently mediates the selective translation of the mRNA encoding the ATF4 transcription factor. This leads to a general inhibition of protein translation, a reduction of the influx of proteins into the ER and an increased expression of different pro-survival genes.ATF6 similarly influences gene expression. It is translocated from the ER to the GA, where it is processed by proteases into the transcription factor ATF6f fragment, which targets UPR genes within the nucleus. Finally, IRE1, dimerizes and autotransphosphorylates under ER stress conditions, resulting in both kinase and endoribonuclease activity (RNase). The latter exerts its activity on the mRNA coding for the transcription factor X box-binding protein (XBP1) by excising a 26nucleotide-long intron. The spliced form of XBP1 is an active and stable transcription factor which translocates to the nucleus, regulating UPR genes. IRE1 can also target and degrade varied mRNA (IRE-1 dependent degradation - RIDD) thus, also contributing to a decrease in protein synthesis [22].

Under conditions of prolonged oxidative stress, homeostasis/proteostasis may not be restored, and cell death mechanisms, for instance apoptosis, are instead activated [23, 24]. Cell death upon unresolved ER stress has been described as dependent on the mitochondrial apoptosis pathway which is regulated by the B cell lymphoma 2 (BCL-2) protein family. C/EBP-homologous protein (CHOP), also known as growth arrest and DNA-damageinducible gene 153 (GADD153), is under the control of the PERK-ATF4 axis of ER stress and is an important pro-apoptotic player through modulation of the expression of different BCl-2 family members. This includes the downregulation of the pro-survival $\mathrm{BCl}-2$ and the upregulation of the pro-apoptotic BCl-2-like protein 11, commonly called Bim [23]. ER stress also participates in the mitochondrial cell death mechanisms by triggering calcium $\left(\mathrm{Ca}^{2+}\right)$ fluxes between the two organelles [25]. Often, upon ER stress, a rapid release of $\mathrm{Ca}^{2+}$ occurs from the ER to the cytosol, which is then captured by mitochondria contributing to mitochondria swelling with rupture of the outer membrane. In turn, the release of mitochondrial apoptotic factors into the cytosol occurs. Additionally, $\mathrm{Ca}^{2+}$ activates the $\mathrm{Ca}^{2+}$ dependent protease calpains, which subsequently activates the caspase 12, an ER resident caspase that translocates to the cytosol, where it directly activates the cascade, caspase 9 caspase 3 [26]. The IRE1 sensor can also have an important pro-apoptotic role through its ability to activate MAPKs pathway and the downstream JNK [23, 24]. Thus, if it is not possible to restore homeostasis following oxidative stress, pro-apoptotic mediators, including CHOP and calcium fluxes will promote cell death.

Numerous works have revealed ER stress activation after PDT, particularly when photosensitizers known to accumulate in the ER were used. A study using 5,10,15,20tetraphenylporphyrin (TPP) derivatives demonstrated the sensitivity of PS functionalization to altering localization. TPP with an ethylene glycol (EG) chain in the meta [mTPP(EG)4] or in the para [pTPP(EG)4] positions of the phenyl ring and a fluorinated analog carrying the EG chain in para position [pTPPF(EG)4] were investigated. While both pTPP(EG)4 and pTPPF(EG) 4 accumulated in the lysosomes. Alternatively, the meta derivative mTPP(EG)4 showed ER tropism. Although the three compounds, when photo-activated, induced 
apoptosis, a rapid increase (within one minute) of the cytosolic $\mathrm{Ca}^{2+}$, followed by activation of calpains, caspase 12 and 4, was only observed for the meta derivate. Pre-treatment with BAPTA (intracellular $\mathrm{Ca}^{2+}$ chelator), Ru360 (inhibitor of mitochondrial $\mathrm{Ca}^{2+}$ uptake) or PD150606 (calpains inhibitor) significantly decreased mTPP(EG)4 toxicity, but not the toxicity of the para derivates. Thus, the involvement of $\mathrm{Ca}^{2+}$ signaling in mTPP(EG)4-PDTmediated apoptosis was suggested. In agreement, PERK and eIF2 $\alpha$ phosphorylation along with induction of ATF4 and CHOP was observed for mTPP(EG)4-PDT, but not for the para counterparts [17]. Microarray technology was used for the identification of the changes in the gene profile after PDT with hypericin, a natural photosensitizer with tropism for the ERGA complex [27]. The most significant changes identified, consisted in the upregulation of several UPR genes, namely PERK and its substrate eIF2 $\alpha$, CHOP and the downregulation of the phosphatase PPP1R15A (GADD34), which indicates activation of PERK-ATF4 axis of the ER stress pathway. Activation of the IRE1 $\alpha$-XBP1 branch was observed, too [28]. Furthermore, in vitro work confirmed PERK and eIF2 $\alpha$ phosphorylation alongside CHOP and the BH3-only proteins (Bim and Noxa) consistent with the ER stress response[29, 30]. PDT using other photosensitizers with ER tropism such as Rose Bengal [31], methyl pyropheophenylchlorin $\left(3^{1}, 3^{2}\right.$-didehydrophytochlorin methyl ester) [32] and 5-ethylamino9-diethylaminobenzo[a]phenoselenazinium (EtNBSe) [33] have also induced signs of ER stress, namely at the PERK-eIF2 $\alpha$ axis. This was correlated with increased levels of GRP78/Bip and CHOP and caspase 12 dependent apoptosis. In contrast, PDT with redaporfin, a bacteriochlorin that accumulates in the ER-GA complex, triggers eIF $2 \alpha$ phosphorylation by EIF2AK1 (also known, HRI) and not by PERK, which was in fact, as revealed for other ER-GA proteins, destroyed by redaporfin photoactivation. The involvement of HRI was unexpected as, unlike other eIF2 $\alpha$ kinases which have a ubiquitous distribution, EIF2AK1 is mainly presented in red blood cells, where it is activated upon heme perturbation. Arsenite treatment, heat shock, osmotic stress, proteasome inhibition and nitric oxide are some other examples that revealed HRI as the kinase mediating eIF $2 \alpha$ phosphorylation. Surprisingly, redaporfin-based PDT failed to elicit the activation of ATF4 and CHOP, the two transcription factors downstream of eIF $2 \alpha$ phosphorylation despite other signs of ER stress being observed, namely at the level of ATF6 and IRE1. Overall, a partial reduction in protein synthesis was observed and gene knockout (KO) of EIF2AK1 (but not that of $E I F 2 A K 2, E I F 2 A K 3$ or $E I F 2 A K 4$ ) sensitized the cells to redaporfin-dependent phototoxicity $[34,35]$.

\subsection{Antioxidant stress response: The Nrf2 pathway}

ROS generated by PDT are detrimental to numerous bimolecules upon oxidation leading to structural modification and loss of function. In an attempt to reinstate redox homeostasis, cells can activate the nuclear factor erythroid 2-related factor ( $\mathrm{Nrf} 2)$, a transcription factor that controls the expression of genes having a role in the elimination of oxidized biomolecules and electrophilic agents. Under normal conditions, Kelch-like ECH associated protein 1 (Keap1) maintains Nrf2 at the cytosol and facilitates its polyubiquitination favoring its degradation by the ubiquitin-proteasome pathway. However, in oxidative stress conditions, Keap1 becomes oxidized and loses the ability to retain Nrf2, which in turn 
translocates to the nucleus, where it binds to antioxidant response element sequences (ARE) to activate the expression of several genes contributing to the restoration of the redox balance. These genes include: a) antioxidant enzymes (e. g. NADPH Quinone oxidoreductase-1 (NQO1), NADPH Quinone oxidoreductase-1 (NQO2), glutathione (GSH), glutathione Stransferases (GST), heme-oxygenase-1 (HO-1), superoxide dismutase (SOD), catalase, etc.), and b) multidrug transporters (e. g. ATP binding cassette subfamily $\mathrm{C}$ (ABCC) also known as multidrug resistance proteins (MRPs) and the multidrug efflux pump ATP-binding cassette subfamily G member 2 (ABCG2), etc.). The first directly neutralize ROS and their intermediates. The latter contribute to the detoxification of cells from oxidized material, which cumulatively contributes to restoration of redox balance $[20,36]$.

These mechanisms have been described in the context of PDT mainly as pro-survival mechanisms. HO-1 upregulation was identified in cancer cells treated by hypericin-PDT [28] [37], photofrin-PDT [38], 5-aminolevulinic acid (ALA)-PDT [39] and talaporfin sodiumPDT [40]. For instance, with hypericin-PDT, the nuclear accumulation of Nrf2 was accompanied by $\mathrm{p} 38$ mitogen activated protein kinases (MAPKs) and phosphatidylinositol 3-kinases (PI3K) signaling cascades, revealed asrequired for $\mathrm{HO}-1$ induction. Pharmacological inhibition or gene silencing of such pathways decrease HO-1 levels and heightens cell sensitivity to the PDT treatment. Similarly, inhibition of HO-1 significantly increases cancer cell death upon treatments of PDT with photofrin, ALA and talaporfin sodium. Thus, it is suggested that HO-1 inhibition is a promising approach to potentiate the effectiveness of PDT, particularly when cancer is the target disease due to the upregulated NFR2 activity often experienced by malignant cells. In addition, NRF2 pathway inhibition can also suppress the subsequent endogenous ROS that are typically generated when cells are stressed. Other studies of PDT treatments with ALA, protoporphyrin IX or pheophorbide have revealed that, besides induction of $\mathrm{HO}-1$, the $\mathrm{ABC}$ transporter, $\mathrm{ABCG} 2$, was also upregulated [41, 42]. NRF2 inhibition in cell lines submitted to pheophorbide a (Pba)-PDT or methyl pyropheophorbide a (Mppa)-PDT resulted in enhanced cytotoxicity along with increased levels of ROS, which were also correlated with decreased levels of drug transporters (BCRP; ABCG2) and increased accumulation of the photosensitizers inside the cancer cells $[43,44]$. The Nrf2 pathway presents several upregulated antioxidants which may also be targeted to enhance PDT efficacy. For instance, SOD (diethyl-dithiocarbamate, DDC and 2-methoxyestradiol, 2-ME), glutathione (L-buthionine sulfoximine, BSO) or catalase (3amino-1,2,4-triazole, 3-AT) inhibitors have been used to potentiate PDT with different photosensitizers [45-52].

All the previously mentioned pathways target homeostasis recovery and cell survival. However, when oxidative stress exceeds a certain intensity or duration, the induction of cell death mechanisms is inevitable.

\section{Cell death pathways in PDT}

The imbalance between the emergence of ROS and the ability of cells to achieve detoxification or repair damage can result in oxidative stress which ultimately triggers different mechanisms of cell death. Our understanding of these mechanisms continue to expand and new mechanisms and signaling pathways are continuously discovered. The 
different forms of cell death are remarkably complex and sometimes partially overlap, which makes their identification a difficult task. Necrosis, apoptosis, and autophagy (Figure 3) are still the best known forms of cell demise although terms like necroptosis, ferroptosis, pyroptosis, parthanatos, mitochondrial permeability transition-driven necrosis, lysosomedependent cell death, cellular senescence, mitotic catastrophe and immunogenic cell death have emerged [53], including evidence within the field of PDT [54-57]. The identification of these different pathways must take into consideration morphological, genetic, biochemical, molecular and functional parameters, as was described in the last recommendations of the nomenclature committee on cell death 2018 [53].

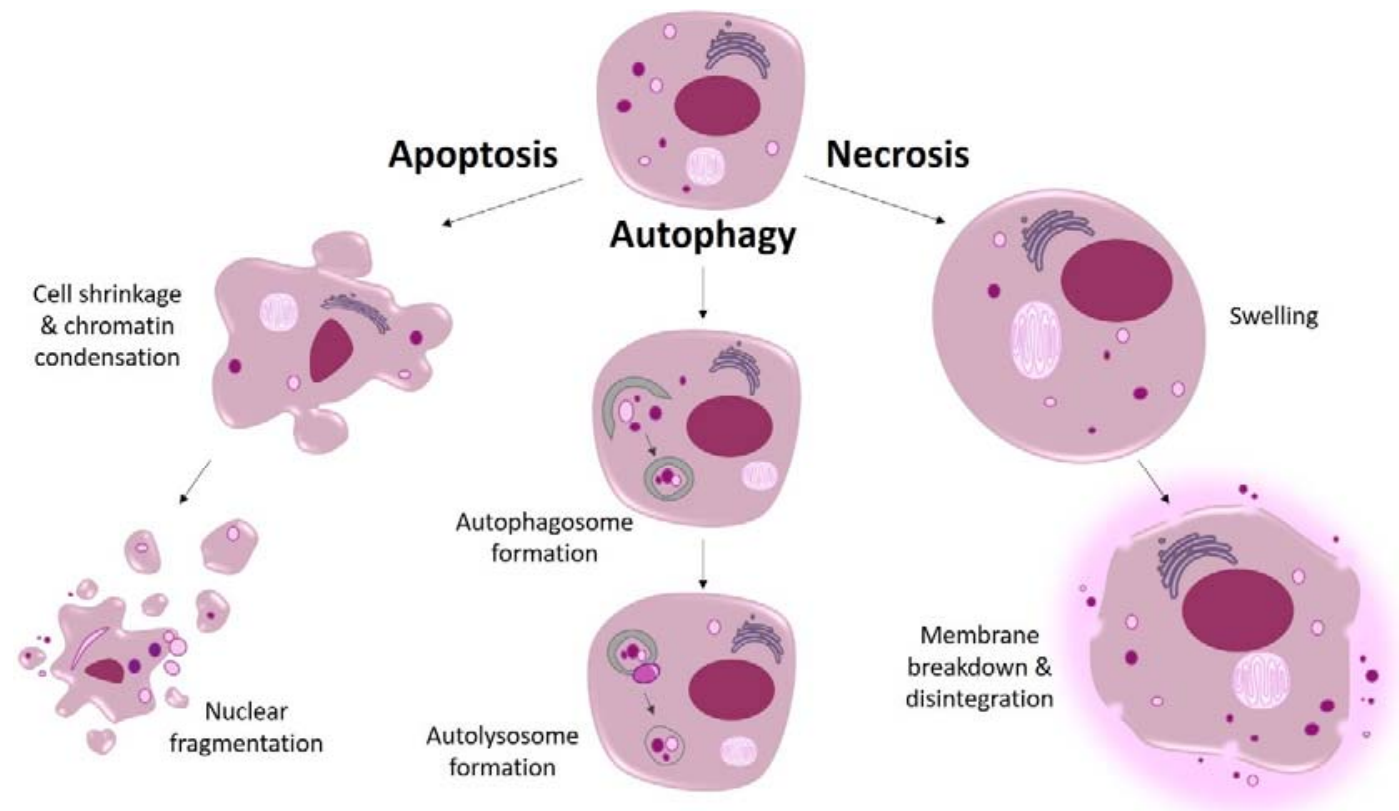

Figure 3 The three most noted pathways of cell death.

Apoptosis is represented with the characteristic cellular shrinkage, chromatin condensation and fragmentation, cell blebbing and formation of apoptotic bodies without leakage of its content. Necrosis shows cytosol and organelles swelling with subsequent membrane breakdown and content release. In autophagy, autophagosomes formation and their fusion with lysosomes forming autolysosomes are the most characteristic features, but sometimes vacuolization can also occur.

Non-regulated cell death (NRCD) or accidental cell death (ACD), typically known as accidental necrosis, is a form of rapid and uncontrolled demise of cells when exposed to severe damage. In contrast, the different modalities of regulated cell death (RCD) are very complex and controlled by several signaling pathways, which can be modulated by pharmacological or genetic interventions. It can occur under physiological conditions, witnessed during development and tissue turnover (programmed cell death), or mediated by 
external factors that induce perturbations/damage which the different adaptive responses discussed previously cannot adequately correct [53].

Apoptosis, autophagy and necrosis are, within the context of PDT, likely the most extensively studied modes of killing. The same photosensitizer may induce the three cell death mechanisms depending on the treatment conditions. Typically, high photo-damage (high photosensitizer concentration and/or high dose light) induces necrosis. Moderate damage is expected to induce regulated cell death modalities (e.g., apoptosis). Finally, minor damage induces autophagy, most probably adaptive autophagy which, depending on the damage extension, can further trigger other mechanisms of regulated cell death $[58,59]$. Taking these into consideration, it is then perceived that, in vivo, different forms of cell death are simultaneously induced within a tumor submitted to PDT. At the tumor surface, where the photon flux is higher, and in regions closer to the tumor blood vessels, the oxidative stress is expected to be stronger, thus generating accidental necrosis. In contrast, cells in deeper regions, further away from the blood vessels may die by regulated forms of cell death (e.g., apoptosis), and autophagy is expected in regions where less ROS are generated.

\subsection{Accidental necrosis (Non-regulated cell death)}

Necrosis or accidental cell death is a rapid and unregulated form of cell death caused by an acute and strong physical or chemical insult. This process leads to failure of the ionic pumps in the plasma membrane. It is accompanied by increased membrane permeability resulting in water and ion influx, cellular and organelle swelling, cytoplasm blebbing and chromatin clumping [60]. Necrosis is regarded as a passive process as in contrast to regulated cell death modalities, it does not require protein synthesis, energy or regulation by signaling pathways. Some investigations point out important roles of mitochondria, ER and lysosomes in the control of necrosis [61]. For instance, the breakdown of lysosomes mediates the release of numerous enzymes to the cytoplasm, namely proteases such as cathepsins and calpains. Elevated cytoplasmic $\mathrm{Ca}^{2+}$ is also observed, which is critical to activate the calpain family and for the translocation of cytosolic phospholipase $\mathrm{A}_{2}$ to cellular membranes, which together mediate the disruption of the cell membrane [60]. The breakdown of the plasma membrane releases all the cellular content leading to a strong inflammation [62]. It is generally accepted that high-dose PDT, either by applying a high photosensitizer concentration and/or a highdose light tends to kill cells by necrosis [14, 63-65].

Necrosis is also associated with photosensitizers having tropism for the cell membrane, which, upon photoactivation, mediate the loss of membrane integrity and ATP depletion. It is understood that short periods of incubation favor the accumulation of the photosensitizers in the plasma membrane, whereas, longer periods of incubation enable accumulation of the photosensitizers in the different organelles. Cells incubated with Photofrin for short period of times (such as $1 \mathrm{~h}$ or $3 \mathrm{~h}$ ) exhibited photosensitizer accumulation mainly in the plasma membrane, whereas longer incubation times $(24 \mathrm{~h})$ resulted in preferential photosensitizer accumulation in the GA. Interestingly, upon photo-activation, the first protocol favored cell demise by necrosis, whereas apoptosis was observed when GA was the target organelle [66, 67]. Similar results were observed with (phthalocyaninato) zinc(II)-PDT. Following a short period of incubation $(2 \mathrm{~h})$, a necrotic phenotype was induced which correlated with loss of 
membrane functions, whereas the same concentration, after $24 \mathrm{~h}$ of incubation, induced GA damage and cell death by apoptosis [68]. Another study of PDT using a glycosylated chlorin as photosensitizer $\left(\mathrm{GLc}_{4}\right)$ also revealed that short periods of incubation $(2 \mathrm{~h})$ confined the photosensitizer at the plasma membrane, resulting in necrosis and demonstrating plasma membrane accumulation as a preferential target for necrosis.[69]

\subsection{Regulated forms of necrosis}

Nowadays, it is generally accepted that necrosis can also occur in a highly regulated manner. Multiple pathways of regulated necrosis have emerged, such as necroptosis, parthanatos, oxytosis, ferroptosis, NETosis, pyronecrosis and pyroptosis. In general, these forms of regulated necrosis are morphologically similar with the non-regulated form of necrosis with cellular leakage, cytoplasmic granulation and cellular and organelle swelling (oncosis). All of these new forms of regulated necrosis have been discussed in detailed in other reviews.[70, 71]

Necroptosis is the best understood example of regulated necrosis and the only mechanism already identified in a few PDT studies. Necroptosis is triggered when perturbations (stress signals, both intra or extracellularly) are detected by death receptors (e.g. TNFR1, FAS, PRRs), particularly when caspases are inhibited (namely caspase 8). One of the best-known triggers of necroptosis is the combination of TNF $\alpha$, a SMAC mimetic and a pan caspase inhibitor. TNF $\alpha$ is detected by TNFR1, which then attracts FADD and receptor interactingprotein kinases 1 (RIPK1) and 3 (RIPK3). The mutual phosphorylation of RIPK1 and RIPK3 induces the formation of a multiprotein RIPK1-RIPK 3 complex, known as necrosome that stimulates necroptosis by recruiting the mixed lineage kinase domain-like (MKLK) protein. The latter is phosphorylated by RIP3K which triggers MLKL

oligomerization and translocation to the plasma membrane. This mediates plasma membrane permeabilization and consequently, cell demise.[70, 71]

Recently, a few studies have highlighted necroptosis as a cell death mechanism activated by PDT. 5-ALA-PDT was immediately followed by an autophagic survival mechanism that was dependent on TSC 2 phosphorylation. This mechanism was shown to be counter-balanced by the activation of RIP3, which dephosphorylates TSC2 inhibiting its pro-survival action and inducing a necroptosis cell death mechanism.[72] Interestingly, the latter occurs in the absence of SMAC mimetics and caspase inhibitors and is characterized by a RIPK1-RIPK3 necrosome that lacks casp8 and FADD. In accordance with these observations, less cell death was attained when 5-ALA-PDT was performed after pre-treatment with necrostatin 1 (NEC1, a RIPK1 inhibitor) or silencing of RIP3K.[73] PDT with the photosensitizer talaporfin sodium also kills cancer cells by using the necroptotosis machinery as suggested by the lower levels of cell death observed upon pre-treatments with NEC1 or alternatively silencing of RIPK3 or MLKL.[57]

PDT with meso-tetrakis (4-carboxyphenyl) porphyrin sodium slat (Na-H2 TCPP) and its zinc derivative Na-ZnTCPP tested in a non-tumoral (MCF-10A) and tumoral (SKBR3) breast epithelial cell lines induced different cell death types. Interestingly, the cancer cells mostly exhibited signs of apoptosis or accidental necrosis, whereas the non-cancer cells presented signs of accidental necrosis but also a form of regulated necrosis known as parthanatos. The 
latter is characterized by nuclear fragmentation, absence of membrane blebbing, mitochondrial depolarization, apoptosis-inducing factor (AIF) translocation from the mitochondria to the nucleus and Poly(ADP-ribose) polymerase (PARP)-dependence.[55] As these modalities of regulated cell death are becoming more known and recognized, it is likely that future works will focus on regulated necrosis with PDT, through the use of different photosensitizers.

\subsection{Apoptosis}

Apoptosis is a very complex mechanism, typically classified in two main pathways, the intrinsic (or mitochondrial) and the extrinsic (death receptor). The first pathway can be triggered by intracellular or extracellular perturbations involving the permeabilization of the outer membrane of mitochondria and culminates in the activation of the effector caspases (caspase 3 and 7). The extrinsic pathway occurs when perturbation at the extracellular environment is detected by plasma membrane receptors, with the specific involvement of caspase 8 , and also ends in the activation of the effector caspases. In both pathways, plasma membrane integrity is always maintained in vivo, with the dying cells and apoptotic bodies being rapidly cleared by immune cells with phagocytic activity (e.g., macrophages), whereas in vitro, membrane breakdown occurs, typically designated as secondary necrosis [74]. Intrinsic apoptosis is the most common within PDT treatments beinh the one herein discussed. It is highly regulated by the B-cell lymphoma 2 (BCL-2) family that, according to their BCL-2 homology (BH) domain organizations, is divided into: a) anti-apoptotic proteins and b) pro-apoptotic proteins. The first has all the four $\mathrm{BH}$ domains $(\mathrm{BH} 1, \mathrm{BH} 2, \mathrm{BH} 3$ and BH4) and includes the BCL-2 itself, BCL-extra large (BCL-X $\mathrm{X}_{\mathrm{L}}$, myeloid cell leukemia-1 (MCL-1), BCL like 2 (BCLL2, best known as BCL-W), and BCL-family member A1 (BFL1) proteins. The latter includes proteins with the $\mathrm{BH} 1, \mathrm{BH} 2$ and $\mathrm{BH} 3$ domains (e.g., BCL2 associated X (BAX), BCL2 antagonist killer 1 (BAK1) and BCL2 family apoptosis regulator $(\mathrm{BOK}))$ and proteins that contain only the $\mathrm{BH} 3$ domain, commonly known as BH3-only proteins (e.g., BCL2 associated death promoter (BAD), BH3 interacting domain death agonist (BID), p53-upregulated modulator of apoptosis (PUMA), BCL2-interacting mediator of cell death (BIM) and phorbol-12-myristate-13-acetate-induced protein 1 (PMAIP1, best known as NOXA)) [75]. Intrinsic apoptosis may result from direct damage at the mitochondria or can be indirectly stimulated by signaling pathways activated due to damage inflicted to other cellular structures. Persistent homeostasis perturbation/damage at sites alternative to the mitochondria (like ER) induces the activation of BH3-only proteins BID, BIM, PUMA and NOXA proteins, which in turn activate BAX and BAK1 proteins to form pores at the outer mitochondrial membrane. This step of mitochondria membrane permeabilization is irreversible and triggers the dissipation of the mitochondrial membrane potential $\left(\Delta_{\psi m}\right)$ and the release of mitochondrial proteins $(e . g$. second mitochondrial activator of caspases (SMAC) and cytochrome c) into the cell cytosol. SMAC binds to members of the inhibitor of apoptosis protein family (IPA) including the X-linked inhibitor of apoptosis (XIAP) known to physically block caspases. Cytochrome c binds to APAF1 and pro-caspase 9 to form a complex known as apoptosome, which can trigger caspase 9 activation, in turn, mediating the proteolytic activation of the effector/ executioner caspases 3 and 7 . The former 
cleave different cellular substrates, which leads to the morphological and biochemical changes typically observed during apoptosis. This includes phosphatidylserine exposure and DNA fragmentation elicited by caspase 3. Activated BAX and BAK can also permeabilize the ER membrane (especially in the context of ER stress) which mediates the release of ER chaperones and $\mathrm{Ca}^{2+}$ to the cell cytosol. The latter is taken up by mitochondria and contributes to its permeabilization. Mitochondrial membrane permeabilization can be impaired by antiapoptotic members of the BCL-2 family (BCL2 itself, BCL-X, MCL-1, BCL-W, BFL-1), which are generally associated with the outer mitochondrial and the ER membranes. They inhibit apoptosis by directly interfering with the pro-apoptotic members of the BCL-2 family, namely BAX and BAK, preventing their oligomerization and pore-forming activity through physical sequestration at the outer mitochondrial membrane and indirectly by inhibition of BH3-only activators $[74,75]$.

In various cell lines, changes in the levels of BCL-2 family members were reported for PDT treatments with different photosensitizers. An increased ratio of pro vs. anti-apoptotic proteins, for example, the BAX/BCL-2 ratio is typically observed. Accumulation of the photosensitizer in the mitochondria has been associated with the destruction of anti-apoptotic proteins, includingBCL-2 itself. This destruction has been witnessed for. PDT with 5aminolevulinic acid (ALA) [76, 77], a silicon(IV) phthalocyanine photosensitizer ('Pc4') $[78,79]$, tin etiopurpurin ('SnEt2', (dichloro)(2 ${ }^{1}$-ethoxycarbonyl-2,7,12,17-tetraethyl3,8,13,18-tetramethyl cyclopenta[at]porphyrinato)tin(IV)), 9-capronyloxy-2,7,12,17tetra(methoxyethyl)-porphycene ('CPO'), temoporfin [80] or (phthalocyaninato)zinc(II) [81]. In contrast, BAX was found to be upregulated at the mitochondrial membrane. This was correlated with the release of mitochondrial proteins such as cytochrome c. Photosensitizers which target the ER-Golgi compartments, such hypericin and redaporfin, can also activate the intrinsic pathway of apoptosis. In both cases, increased levels of cytosolic $\mathrm{Ca}^{2+}$ were observed, likely reflecting the direct damage at the ER. Upon $\mathrm{Ca}^{2+}$ inhibition, for instance with the $\mathrm{Ca}^{2+}$ chelator BAPTA, reduced cell toxicity was detected [35]. Hypericin-PDT demonstrated destruction of the anti-apoptotic BCL-XL [82] but also the activation of the PERK-eIF2 $\alpha$ arm for ER stress. Induction of the downstream player CHOP thereby occured. CHOP is a pro-apoptotic transcription factor which increased the expression of the pro-apoptotic proteins BIM and NOXA, with subsequent BAX and BAK activation [29, 30, 83]. Silencing of NOXA, but not of BIM, reduced cell death. Additionally, PERK KO cells were less sensitive to hypericin-PDT-mediated photodamage, which was related to the inability of these cells to upregulate NOXA. The latter was independent of CHOP, thus suggesting that PERK was regulating apoptosis via two independent pathways: CHOP induction and NOXA upregulation [84]. In another study with hypericin-PDT, it was demonstrated that upregulation of BAX and/or BAK resulted in higher photo-toxicity, whereas their inhibition decreased cell demise, although, not completely. This suggested that other mechanisms, likely caspase-independent, are involved. In fact, wild-type (WT) cells presented the typical signs of apoptosis, whereas, cells $\mathrm{KO}$ for $B A X$ and $B A K$ presented an accentuated cytosolic vacuolization. The former was prevented by wortmannin (PI3K inhibitor) but not by zDEVD-fmk (caspase inhibitor) suggesting that in the absence of the 
pro-apoptotic proteins BAX and BAK, hypericin-PDT results in autophagy-dependent cell death instead of apoptosis $[83,85]$.

Recent work revealed redaporfin-PDT as causing a rapid dilation and vacuolization of the ER-GA organelles, as well as reducing the level of several GA/ER proteins. Redaporfinbased PDT manifested traits of the intrinsic pathway of apoptosis, mainly: translocation of $\mathrm{BAX}$ to mitochondria and mitochondrial release of SMAC with partial dependency on caspases, BAX and BAK, for its toxicity. Surprisingly, pharmacological perturbation of GA function or homeostasis by means of Brefeldin A or Golgicide A, reduced mitochondrial permeabilization and, as consequence, cell death-mediated by redaporfin-PDT. In contrast, removal of the pro-apoptotic proteins BAX and BAK or pre-treatment with the pancaspase inhibitor Z-VAD-fmk, reduced cell killing but left the GA perturbation unaffected. These effects were mitigated by the lipophilic antioxidant tocopherol, thus indicating that they were ROS-mediated [34, 35]. PDT with protoporphyrin IX, or polyamines-targeting derivatives, were shown to accumulate at the cells cytoplasm but also mediate cell death by activating apoptosis via the intrinsic pathway. [86]

\subsection{Autophagy}

Autophagy is a catabolic process which can act as: a) a pro-survival mechanism (adaptive autophagy) through the clearance of damaged cellular material, or b) a death mechanism, particularly under conditions which permanently enhance organelle damage (autophagydependent cell death). Each case relies on the formation of a double layer membrane vesicle that engulfs damaged material (autophagosomes) separating it from the cytoplasm, followed by fusion with lysosomes (causing the digestion of the inner membrane of the autophagosomes) forming the so-called autolysosome (single-membraned vesicles). It is here that the autophagic cargo is degraded by lysosomal hydrolases. The degradation allows for both the removal of damaged material (unfolded proteins, damaged organelles, microorganisms) and reuse of recycled nutrients for normal cellular processes. The formation of autophagosomes is a highly complex and regulated process involving numerous proteins and signaling pathways, such as: a) unc-51 like autophagy activating kinase 1 (ULK1) complex, b) phosphatidylinositol 3-kinase catalytic subunit type 3 (PIK3C3, known as VPS34) - Beclin 1 (BECN1) complex, and c) several other autophagy-related genes (ATG). Microtubule-associated protein 1A/1B light chain 3B (MAP1LC3B, best known as LC3 is also a critical protein for the autophagosomes biogenesis as well as for their cargo selection. It is redistributed from a usually diffuse cytoplasmic pattern (LC3-I) towards the so-called autophagic puncta (LC3-II), which requires a series of ubiquitin-like reactions (involving several ATGs) which mediate the conjugation of LC3-I to the phosphatidylethanolamine lipid of the autophagic vesicles, yielding LC3-II. Lipidation of LC3 and the detection of LC3+ puncta are, indeed, the most common markers for the recognition of autophagy.[53] The presence of autophagosomes in dying cells is not a definite indicator that autophagy is the cause of demise. Rather, it may reflect the efforts of the cells to rescue homeostasis and survive [53, 87]. Moreover, autophagy is often associated with the presence of other types of regulated cell death, such as apoptosis or necroptosis, serving a less significant role in the cell demise. Autophagy-dependent cell death is considered a regulated form of cell death that 
fully requires different components of the autophagic machinery. Currently, tissue development is the most frequently used used model to study this type of cell death. Recent efforts have started to highlight the molecular and morphological features of autophagy stimulated cell demise and how the autophagic pathway changes from a survival to a death role [88].

Function of autophagy as a survival of death mechanism depends on the degree of photodamage induced. Upon autophagy activation, demise can occur directly as a result of the action of the autophagic machinery (autophagy-dependent cell death) or by activating other modalities of regulated cell death (typically apoptosis) [31, 89]. Numerous studies in the PDT field show that the pharmacological or genetic inhibition of autophagy often increases the phototoxicity of ROS-mediated damage, thus suggesting autophagy as a survival mechanism rather than a cell death pathway. For example, PDT with the photosensitizer CPO or with hypericin (both with ER tropism) revealed apoptosis-induction with the concomitant identification of signs of autophagy, such as double-membrane autophagosomes, lipidation of LC3, and cytoplasm vacuolization. In both studies, inhibition of autophagy, either by PI3K inhibitors (e.g., wortmannin) or by silencing autophagic genes (e.g., ATG5), resulted in cell death augmentation which clearly revealed the cytoprotective role of autophagy for these photosensitizers [90-92]. However, this pro-survival effect can only occur up to a certain threshold of photodamage as illustrated by some studies of PDT using CPO (ER tropism), mesochlorin (2,3-dihydro-mesoporphyrin, mitochondria tropism) or verteporfin (mitochondria tropism). These studies demonstrated that increased cytotoxicity occurred in autophagic-deficient cells $(A T G 7 \mathrm{KO})$ but only when low light doses were applied [93, 94]. Interestingly, different effects were found with PDT using photosensitizers targeting lysosomes (WST11 or NPe6). Although autophagy (observed by vacuolization and LC3 lipidation) was inhibited in both $A T G 5$ and $A T G 7 \mathrm{KO}$ cell lines, no differences on the cell viability were found between normal and ATG5 $\mathrm{KO}$ cells, whereas cell death (apoptosis) was significantly suppressed in $A T G 7 \mathrm{KO}$ cells. In all these cell lines, rapid photodamage of the lysosomes was observed, while lysosomal recovery was not observed for normal or ATG5 KO cells. Instead, it was rapidly attained in ATG7 KO cells, which likely explains the better survival of such cells [95].

Autophagy-dependent cell death triggered by PDT appears to mainly occur when apoptosisdeficient cells are used. Cell death in the absence of apoptosis signsbut with LC3 lipidation and strong vacuolization, were observed upon CPO-PDT in BAX-deficient cells, which was significantly repressed by PI3K inhibitors $[90,91]$. Similarly, cell death by hypericin-PDT in cells double $\mathrm{KO}$ for $B A X$ and $B A K$ occurs with vacuolization, double-layer vacuoles, LC3 lipidation and LC3-GFP+ dots, but without the features of apoptosis. In accordance, pretreatment with PI3K inhibitors (wortmannin) blocked cell death (and autophagy) in the KO cells but not in the normal cells. Additionally, caspase 3 inhibition (zDEVD-fmk) only affected normal cells [83, 85].

The complexity of autophagy is also reflected by the diverse forms of non-canonical autophagy that have been described in recent years. In this regard, the photoactivation of redaporfin was described to have induced LC3 lipidation, AMPK activation, mTOR inhibition, recruitment of LC3 (and other autophagic proteins) towards the damaged GA but 
not double-membraned autophagosomes. This GA-specific relocation of LC3 was found to be dependent on ATG3, ATG5 and ATG12, yet it did not depend on ULK1 or PIK3C3/BECN1 complexes, or on the lysosomal-autophagosome fusion process. Even though GA recruitment of LC3 appears to occur by a non-canonical form of autophagy, this pathway is potentially cytoprotective as double KO of $A T G 5$ and $A T G 7$, prevented LC3 recruitment also sensitized cells to killing by redaporfin- PDT.[96] Similar results were described for other strategies with the ability to interfere with GA homeostasis. These strategies included laser-induced localized cellular damage, local expression of peroxidase with exposure to peroxide and diaminobenzidine, exposure to the Golgi-tropic anticancer peptidomimetic LTX-401 [96], to the unsaturated fatty acid oleate [97] or to squaramidebased synthetic chloride transporters [98].

\section{PDT and immunogenic cell death (ICD)}

For a long time, apoptosis was considered to be immunologically silent or even tolerogenic, whereas accidental necrosis was perceived as a highly inflammatory, sometimes even harmful, form of cell death. This perception came from the notion that in vivo, apoptotic cells (and related apoptotic bodies) are taken up by phagocytic cells before the breakdown of their membranes, which prevents the release of any intracellular content. Instead, accidental necrosis is accompanied by a rapid release of the intracellular content, which contains several molecules with inflammatory and immunomodulatory properties. These molecules are known as danger/damage-associated molecular patterns (DAMPs) and only acquire immunostimulatory properties when released/exposed and ultimately recognized by patternrecognition receptors (PRRs) (such as Toll-like receptors, NOD-like receptors and RIG-1 like receptors) in immune cells. It is now recognized that apoptosis can, in some situations, activate an adaptive immune response (with immunological memory) against both exogenous (pathogens) and endogenous (tumor) antigens presented in dying cells. This type of cell death is known as immunogenic cell death (ICD). Although ICD is most often associated with signs of apoptosis, novel evidence suggested that other regulated cell modalities, namely necroptosis, can have immunogenicity properties as well [99, 100]. Indeed, the classical necroptosis inducer TSZ (TNF $\alpha+$ SMAC mimetic $+z-V A D-f m k)$ can trigger cell death that exhibit ICD hallmarks (ATP, CALR, HMGB1). These TSZ-dying cancer cells, when injected in immunocompetent mice, elicit an immune response conferring protection against further rechallenge with live cancer cells. However, genetically inhibition of RIP3K or MLKL significantly abrogate the immunogenicity of necroptotic cells, thus suggesting that the necroptotic machinery might contribute to ICD. Currently, the nomenclature committee on cell death considers ICD as an independent type of cell death that relies on the emission, in a spatial-temporal controlled manner, of a specific set DAMPs, namely: ER chaperones such as calreticulin (CALR) and heat shock proteins (HSP), adenosine triphosphate (ATP), type I interferon (IFN), high-mobility group box 1 (HMG $\beta 1$ ) and annexin A1 (ANXA1) (Figure 4). Vaccination experiments in which murine dying cells are injected into immunocompetent mice are the gold-standard approach to determine whether a certain strategy immunogenic $[101,102]$. 


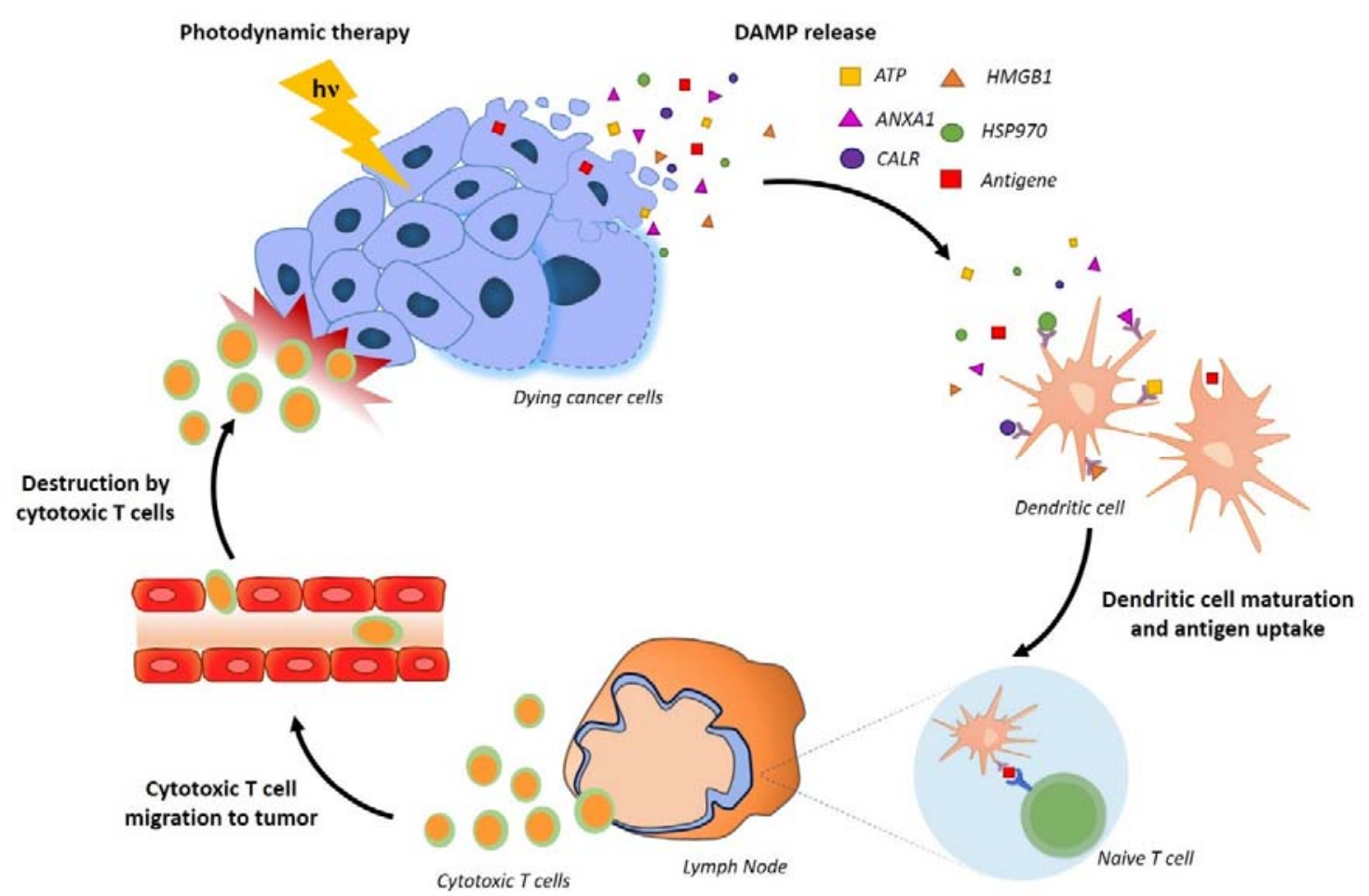

Fig. 4 DAMPS and anti-tumor immunity.

Photodynamic therapy triggers different forms of cell death that are associated with a strong and acute inflammation with the exposition/release in a spatio-temporal manner of the main ICD hallmarks namely: CALR, HSP, ATP, HMG $\beta 1$, IFN and ANXA1. ATP triggers the recruitment of DCs to the tumor bed and CALR/HSP contribute to the engulfment of tumor antigens by these cells. Stimulated by HMG $\beta 1$, DCs further migrate to the lymph nodes where tumor antigens are presented to T cells. Altogether, this results in a potent IL-1 $\beta$ - and IL-17-dependent, IFN- $\gamma$-mediated immune response involving the activation of cytotoxic CD8+ T cells. Activated T lymphocytes then, migrate through the body and kill the tumor cells, both at the primary site of irradiation and at non-irradiated cancer lesions (metastasis).

\subsection{Danger/damage-associated molecular patterns (DAMPs)}

CALR is mainly localized at the lumen of the ER, where it has diverse functions, such as regulation of $\mathrm{Ca}^{2+}$ homeostasis and chaperone activity to help other proteins proper folding features. When ICD is triggered, CALR translocates from the ER lumen to the cell surface, where it functions as an "eat me" signal, which is recognized by the receptor CD91 expressed on antigen-presenting cells (APCs), for instance, dendritic cells (DCs). This stimulates the engulfment of the dying/stressed cancer cell, including their tumor-associated antigens, as well as the further antigen cross-presentation to the T cells, triggering anti-tumor immunity. CALR translocation to the cell surface was initially identified in treatments with anthracyclines and was described as an early event in the death process, dependent on PERKeIF $2 \alpha$ arm of ER stress, caspase 8 activation, Bap31 cleavage, BAX/BAK activation, 
anterograde ER-Golgi transport and SNARE exocytosis [103, 104]. Recently, it was revealed that ICD inducers definitely manifested PERK-dependent eIF2 $\alpha$ phosphorylation. However, the downstream ATF4 or CHOP activation (as observed in canonical ER stress) or other signs of ER stress (activation of ATF6 or IRE1a arms) were not induced by ICD. This demonstrated that CALR exposure is only dependent on eIF2 $\alpha$ phosphorylation and not on any of the other signs of ER stress $[105,106]$. CALR exposure and phosphorylation of eIF2 $\alpha$ have been associated with a positive prognostic value in cancer patients, which is probably explained by the ability of those patients to elicit ICD when submitted to anti-cancer treatments [107-109].

Similarly to CALR, HSPs are also chaperone proteins with an important role in the folding of newly synthesized proteins but are also important molecular players in the cellular stress response, detecting and re-folding misfolded proteins. Intracellularly, they can mediate prosurvival/cytoprotective effects, but under ICD, translocation into the plasma membrane of HSP70 and HSP90) results in their action as an "eat me signal". This is due to their ability to be recognized by receptors (such as CD91, LOX1 and CD40) on APCs, which in turn, mediates the uptake of dying cells and the cross-presentation of tumor antigens to $\mathrm{T}$ cells facilitating activation. Alternatively, HSP can also be recognized by CD94 receptor of NK cells, which can directly kill cancer cells [101, 102].

During ICD, ATP is actively released by the stressed cells into the extracellular milieu. ATP, a "find me" signal, is known to attract APCs and to promote inflammasome activation by interacting with purinergic $\mathrm{P} 2 \mathrm{Y} 2$ or $\mathrm{P} 2 \mathrm{X} 7$ receptors (P2RY2 or P2RX7). This triggers the release of the pro-inflammatory IL- $\beta$ that, ultimately, activates IFN $\gamma$ and IL17 producing T cells which are known to be crucial to stimulate adaptive immunity. ATP release occurs in the absence of plasma membrane permeabilization and depends on the classical, PERKregulated, proximal secretory pathway (ER-to GA transport) and PI3K-dependent exocytosis. Inhibition of autophagy (by $\mathrm{KO}$ autophagy-related genes) was demonstrated to decrease the ATP release upon treatment with chemotherapeutic ICD inducers (e.g., mitoxantrone) which significantly reduced the recruitment of APCs and T cells in the tumor bed [110]. This was in contrast to the findings obtained with hypericin-PDT, which indicated no dependence on autophagy for ATP release during PDT. In contrast to anthracyclines, autophagic-deficient cells were more immunogenic than normal cancer cells when submitted to hypericin-PDT (increased DC maturation, IL 6 and IFN $\gamma$ production and proliferation of T cells) [111].

HMG $\beta 1$, a nucleus-localizing, non-histone chromatin-binding protein can be actively released from inflammatory cells (activated macrophages and monocytes) or passively from dying cells, therefore it is mainly known as a necrotic DAMP. Extracellular HMG $\beta 1$ acts as a pro-inflammatory "cytokine" upon recognition by diverse PRRs, of which TLR4 is probably the most important in the context of ICD for its role as a pro-inflammatory "cytokine". HMGB1 interacts with TLR4 expressed in DC to stimulate tumor antigen presentation [101, 102].

Finally, the release of ANXA1 by dying cancer cells was recently described to be crucial for the anti-tumor immune response trigger by anthracyclines. The mechanisms of ANXA1 release are not yet known. ANXA1 binds to formyl peptide receptor 1 (FPR1) which is 
mainly expressed on DC and contributes to the migration of these cells towards dead/dying cancer cells. Indeed, cancer cells that lack the ability to release ANXA1 fail to induce antitumor immunity upon treatment with anthracyclines. Similarly, mice lacking FRP1 are also unable to mount an anti-cancer immune response as their DCs are incapable to interact with anthracycline-killed cancer cells and hence, no cross-presentation of tumor-associated antigens occurs to the cytotoxic T lymphocytes.[112] Loss-of-function mutations of FRP1 in cancer patients (namely cancer and colon cancers) have been correlated with shorter metastasis-free and overall survival after treatment with anthracyclines-inducing ICD.[113] ICD was initially thought to be triggered by a small set of chemotherapeutics agents (e.g., doxorubicin, mitoxantrone, oxaliplatin, bortezomib, etc) [104]. Unfortunately, most of the drugs used in chemotherapy (e.g., cisplatin, etoposide, mitomycin C) are unable to induce ICD, meaning that cancer cell destruction is caused in a way that is ineffective regarding immune recognition $[114,115]$. The development of anticancer therapies capable of killing cancer cells and, concomitantly, activating anti-tumor immunity (in the absence of adjuvants) is of the upmost importance for effective systemic therapies. Although PDT has been known for decades to impact the host immune system [116, 117], only recently was it recognized that light-activated photosensitizers can be ICD inducers. The pioneering work by Agostinis et al. with hypericin was particularly significant $[118,119]$. Hypericin was demonstrated to trigger ICD through a pathway involving the PERK-eIF2 $\alpha$ arm of ER stress, exposure of CALR at the cell surface and ATP release. However, the mechanisms described for CALR exposure and ATP release upon hypericin photoactivation are slightly different from the ones identified for anthracyclines. In contrast to the latter, CALR exposure was described to be dependent on PERK but not on eIF2 $\alpha$ phosphorylation or caspase 8 [120], whereas the active release ATP was also found to be independent on autophagy [111, 118, 119]. ICD hallmarks have been reported for different photosensitizers as illustrated in Table1.

Table 2. ICD hallmarks trigger by different light-activated photosensitizers

\begin{tabular}{|l|l|l|}
\hline Photosensitizer & ICD Hallmarks & References \\
\hline Redaporfin & CALR, ATP, HGMB1 and eIF2 $\alpha$-P & {$[34,35]$} \\
\hline Hypericin & $\begin{array}{l}\text { CALR, ATP, eIF2 } \alpha \text {-P, HSP70, HSP90, } \\
\text { CXCL1, CCL2 and CXCL10 }\end{array}$ & {$[120-122]$} \\
\hline Rose Bengal & CALR, ATP, HSP70, HSP90 and HGM $\beta 1$ & {$[123,124]$} \\
\hline 5-Aminolevulinic acid & CALR, HGM $\beta 1$ and HSP70 & {$[125,126]$} \\
\hline Porfimer sodium & CALR, HGM $\beta 1$ and HSP70 & {$[127-129]$} \\
\hline $\begin{array}{l}\text { Glycoconjugated chlorin 'G- } \\
\text { chlorin' (5,10,15,20-tetrakis(4- } \\
\text { ( } \beta \text {-D-glucopyranosylthio)- } \\
\text { 2,3,5,6-tetrafluorophenyl)-2,3- } \\
\text { (methano( } N \text { - } \\
\text { methyl)iminomethano)chlorin) }\end{array}$ & CALR and HGM $\beta 1$ & {$[130]$} \\
\hline Temoporfin & HSP70 & \\
\hline
\end{tabular}

\subsection{PDT-based vaccines}


In addition to the ICD hallmarks detected in vitro, vaccination experiments, conducted in immunocompetent mice, are crucial in the establishment of a therapy involving an ICD inducer [132]. The immunogenicity of dying cancer cells is expected to arise from the combination of antigenicity provided by tumor cell's specific epitopes and the adjuvanticity conferred by the DAMPs.

For many years, even before the appearance of the concept of ICD, PDT was explored for the development of anti-cancer vaccines. The first efforts used lysates/supernatants from Photofrin-PDT treated cells (PDT-based lysates vaccine), which acted as prophylactic vaccines by conferring protection to the mice against tumor growth (mammary EMT6 cells). This study demonstrated that $75 \%$ of the mice had tumors smaller than $400 \mathrm{~mm}^{3}$, three months after cancer cell inoculation, whereas non-vaccinated mice reached the humane endpoint around one month later. Such anti-tumor protection was found to be tumor-specific and correlated with DCs maturation and IL12 production. Importantly, no protection was observed for vaccines prepared by ionizing radiation, UV light, hyperthermia, or freeze/thaw cell lysis [133]. Later, benzoporphyrin derivative (BPD)-PDT-based whole-cell vaccines were used to treat established and low-immunogenic head and neck cancer SCC tumors. A significant tumor growth delay was attained, which was correlated with increased number of $\mathrm{B}$ and T cells and matured DCs on the lymph nodes [134]. PDT with other photosensitizers was explored for the generation of whole-cell vaccines, such as chlorin e6 $[135,136]$, hypocrellin SL052 [137] hematoporphyrin monomethyl ether [138] and redaporfin [35]. In general, these studies revealed that PDT-based whole-cell vaccines are tumor-specific, which means that protection is limited to rechallenge performed with the same cell types as those used for vaccination. Maturation of DCs and interferon-producing T cells are also often reported, as well as the loss of effect when immunodeficient mice were used [139].

Anti-cancer DC-based vaccines have been extensively explored over the last decades as a therapeutic strategy in oncology. DCs are important APCs and their major roles include the uptake, transport, processing and presentation of antigens to CD8 T lymphocytes, which then acquire the ability to recognize and eliminate cancer cells selectively. Therefore, DCs are important players in the establishment of immunological memory, contributing to the transition from innate to adaptive immunity. Anti-cancer DC-based vaccines envisage the use of the patient-derived DCs, which are loaded with ex vivo tumor-associated antigens (TAAs), matured with a combination of pro-inflammatory cytokines and TLR agonists, and ultimately infused back in the cancer patient [140, 141]. Loading DC with TAAs from PDTmediated dying/dead cancer cells might constitute a major contribution to the field and a few promising examples of PDT-based DC vaccines have been reported.

For example, cancer cells killed with PDT using a chlorin-based photosensitizer ('DH-I-1803', a triethylene glycol derivative of methyl pheophorbide a) were used to pulse immature DCs with TAAs. Mature DCs were further administrated to mice (at early or later time points after tumor implementation) and a significant inhibition of mammary tumor growth (EMT6 cells) was observed in both cases, which was correlated with increased IFN $\gamma+$ spleenocytes. In contrast, no tumor delay was achieved in treatments with DCs pulsed with freeze/thawed killed tumor cells, nor when only PDT-based tumor lysates were used [142].ALA-PDTmediated apoptotic cancer cells (skin squamous carcinoma, PECA cells) were also used to 
activate immature DC cells. These DCs revealed morphological maturation (enlargement of dendrites and increase of lysosomes), phenotypic maturation (upregulation of MHC class II, CD80 and CD86) and higher expression of IFN $\gamma$ and IL12 (but low amounts of the immunosuppressive IL10) than those DCs charged with freeze/thawed cancer cells (high IL10). ALA-PDT-based DC vaccines provided protection to mice against a subsequent rechallenge with live cancer cells, while such protection was not attained with freeze/thawedbased DC vaccines [126, 143]. DCs pulsed with apoptotic hypericin-PDT-treated Lewis lung carcinoma (LLC) cells also exhibited phenotypic maturation (CD80, CD86 and CD40) and were capable of stimulating CD8+ $\mathrm{T}$ cells to produce IFN $\gamma$. Preventive vaccination experiments revealed that both dying hypericin-PDT-treated cells and DC pulsed with hypericin-PDT-treated cells conferred protection against tumor growth; although the vaccination via DCs was more efficient than the whole-cell vaccine. In both cases, such protection was correlated with an increase of CD8+ T cells expressing IFN $\gamma$ and decrease of Tregs (CD4+ Foxp3+) [144].

An additional study with hypericin-PDT, involving glioma cancer cells (GL261), likewise demonstrated that these dying cells can efficiently mature DCs. Vaccination experiments revealed that hypericin-PDT-based DC vaccine induced an anti-tumor immune response strong enough to protect around $70 \%$ of the mice against an intra-brain rechallenge with live cancer cells. Freeze/thawed -based DC vaccines instead failed to confer any anti-tumor protection. These results were associated with increased $\mathrm{T}$ cells (both CD4+ and CD8+) expressing IFN- $\gamma$ and IL17 and decreased Tregs within the brain of the vaccinated mice. Importantly, the anti-tumor immunity was significantly abrogated by inhibiting different ICD hallmarks (CALR, ATP, HMGB1), ROS formation, MyD88 (myeloid differentiation primary response gene), $\mathrm{CD} 8+\mathrm{T}$ cells or use of immunocompromised mice. These vaccines were also tested in a curative setting, alone or in combination with temozolomide, the standard-of care for glioma patients. Treatment of mice bearing orthotropic gliomas with hypericin-PDT-based DC vaccine or temozolomide alone resulted in a slight increase of the median survival but without long-term cures, whereas a combination of the vaccine with temozolomide resulted in 50\% tumor-free brain for at least 3 months. The combination resulted in a significant increase of T cells expressing IFN $\gamma$ and IL17 and decrease of Tregs, thus suggesting anti-tumor immunity [122]. Overall, these studies illustrate the immunogenic potential of cancer cells killed by PDT.

\section{Anti-tumor immunity mediated by PDT}

The nexus between cancer cell death and immunogenicity is becoming clear and holds promise of achieving anti-tumor systemic immunity with long-term tumor control. To this end, it was recently established that PDT elicits anti-tumor immunity, meaning that the cancer cells dying in the patient's body after PDT can themselves, behave as a vaccine. This is undoubtedly connected to the cancer cell's death pathways elicited specifically by PDT, which render them immunogenic.

Numerous studies have demonstrated that PDT activates both innate and adaptive immune responses that contribute to tumor eradication [145]. Treatment of tumors with PDT triggers strong and acute inflammation due to the release of a variety of pro-inflammatory cytokines 
(mainly the pro-inflammatory IL6), neutrophil tumor infiltration, neutrophilia and complement activation [146-149]. These observations, already known for many years, are in agreement with the recent finding that ICD triggers a pathogen-like chemokine response similar to the one elicited by some pathogens (namely bacteria and virus). Cancer cells killed by different ICD inducers (mitoxantrone, radiotherapy and hypericin-PDT), but not by nonICD inducers (tunicamycin, cisplatin and F/T killed cells), induce the release of specific inflammatory chemokines (namely CXCL1, CCL2 and CXCL10) and the recruitment of neutrophils, thus resembling bacterial and viral infections. Recruited neutrophils were demonstrated to be able to phagocyte ICD-dying cancer cells. This elicited their phenotypic (CD86/MHC-II) and functional (IL6/IL1B high and IL10 low) maturation, which is correlated with their ability to kill residual cancer cells by means of $\mathrm{H}_{2} \mathrm{O}_{2}$ and NO release.[150]

Neutrophils are the first innate immune responders to PDT which is followed by dendritic cell (DC) maturation and migration to the lymph nodes where they prime tumor-specific cytotoxic CD8 $+\mathrm{T}$ cells. The activity of the primed cytotoxic $\mathrm{T}$ cells is not confined to the local tumor area, but may also include distant sites such as metastases. WST11 (Tookad, bacteriopheophorbidato a)palladium(II)) and redaporfin are good examples of photosensitizers which, when applied in vascular protocols of PDT, were able to induce high cure rates (around 80\%), namely in a mouse model of colon cancer (CT26WT) [12-14, 151]. This therapeutic effect dramatically drops when immunocompetent mice were replaced by immunodeficient mice, or when CD8+ T cells were depleted by using specific antibodies. Cured mice were protected against subsequent challenges with live cancer cells, thereby indicating immunological memory. Of note, such immune responses are strong enough to inhibit the growth of distant and non-irradiated metastasis $[12,151]$.

A few narratives of PDT-mediated anti-tumor immunity in a clinical setting have also been published. A case report of a patient with multifocal skin recurrent angiosarcoma, submitted to chlorin e 6 -PDT, described regression of the irradiated lesion but also of non-treated distant lesions. This effect at distant lesions was correlated with $\mathrm{T}$ cell infiltration $48 \mathrm{~h}$ posttreatment [152]. However, it well known that cancer cells can escape the immune system namely by the presence of immunosupressor cells in the tumor microenvironment. $T$ cells overexpressing the inhibitory receptors (immune checkpoints) CTLA-4, PD-1 and its ligand (PD-L1) are often founded in tumors. The inhibition of these receptors by specific antibodies (typically known as immune checkpoints blockers (ICBs)) has been unprecedentedly successful in some cancer patients, although they still fail in several others for reasons not yet fully understood. Recently, their use as adjuvants for PDT with the aim of boosting the immune system, namely the abscopal effects, has revealed encouraging results. For example, the combination of PDT with Bremachlorin (a mixture of chlorin e6, chlorin $\mathrm{p} 6$ and purpurin 5) with an antibody against CTLA4, in mice bearing two tumors (pseudo-metastatic model, CT26 or MC28 cells) resulted in enhanced eradication of both the primary tumor (irradiated) and the distant and non-irradiated tumors. This therapeutic effect was not achieved with the single treatments and was shown to be dependent on CD8+ T cells [153]. Similarly, PDT using the photosensitizer WST11, combined with antibodies against PD-1 and PD-L1, was demonstrated to be very effective in the treatment of an orthotopic model of renal cancer with 
lung metastases. Regression of the primary renal tumor and of lung metastases was only achieved with the combination approach and not with the single treatments of PDT or ICBs [154]. More detailed revisions about PDT and combinations to boost anti-tumor immunity can be found elsewhere (refs).

Altogether, these results endorse PDT as a therapeutic strategy with immunomodulatory properties that can bring, either alone or in combination with other therapies, significant benefits to cancer patients.

\section{Concluding remarks}

Cancer cell death is an important factor in the design of anti-cancer therapies. The manner in which cancer cells are destroyed strongly determines how they are recognized by the immune system. The anti-tumor immunity triggered by PDT is not expected to be simply mediated by the large extension of unprogrammed necrosis (typically observed in vivo) and the subsequent release of the intracellular content. This supported by the fact freeze-thaw or boiling treatments are known to induce massive necrosis but have failed to protect mice in vaccination experiments. Thus, it is plausible that the oxidative stress mediated by PDT, with some photosensitizers, generates new and unique tumors antigens (neo-antigens) that render PDT-treated cancer cells more immunogenic than cancer cells killed by other strategies. It was shown that oxidation-associate molecular patterns (OAMPs), such as reactive protein carbonyls and peroxidized phospholipids, can be recognized by the immune system and possess immune adjuvant properties similar to those of classical DAMPs [155]. Photosensitizers that target different cells (endothelial vs. cancer cells) or with different subcellular accumulation may also generate distinct neo-antigens and OAMPs/DAMPs, which are expected to be linked with different immunomodulatory properties. The exact mechanisms which mediate anti-tumor immunity in the context of vascular-PDT are still poorly understood, but it is reasonable to think they are not mediated by the ROS-based PERK-eIF2 $\alpha$-ER stress pathway. A detailed understanding of the molecular and biological mechanisms behind PDT-mediated cell death and anti-tumor immunity will enable more effective treatment protocols and combinatory strategies for the benefit of the cancer patient.

\section{Acknowledgments}

This project has received funding from the European Union's Horizon 2020 research and innovation programme under the Marie Sklodowska-Curie grant agreement No 764837 (Polythea - How light can save lives), from Science Foundation Ireland (SFI P.I. 13/IA/1894), and the Portuguese Science Foundation (grants PTDC/QEQMED/3521/2014 and Pest-OE/QUI/UI0313/2014).

\section{References}

[1] J.M. Dabrowski, L.G. Arnaut, Photodynamic therapy (PDT) of cancer: from local to systemic treatment, Photochem Photobiol Sci, 14 (2015) 1765-1780.

[2] B. Chen, B.W. Pogue, P.J. Hoopes, T. Hasan, Vascular and cellular targeting for photodynamic therapy, Crit Rev Eukaryot Gene Expr, 16 (2006) 279-305. 
[3] P. Agostinis, K. Berg, K.A. Cengel, T.H. Foster, A.W. Girotti, S.O. Gollnick, S.M. Hahn, M.R. Hamblin, A. Juzeniene, D. Kessel, M. Korbelik, J. Moan, P. Mroz, D. Nowis, J. Piette, B.C. Wilson, J. Golab, Photodynamic therapy of cancer: an update, CA Cancer J Clin, 61 (2011) 250-281.

[4] M.R. Detty, S.L. Gibson, S.J. Wagner, Current clinical and preclinical photosensitizers for use in photodynamic therapy, J Med Chem, 47 (2004) 3897-3915.

[5] R.R. Allison, G.H. Downie, R. Cuenca, X.H. Hu, C.J. Childs, C.H. Sibata, Photosensitizers in clinical PDT, Photodiagnosis Photodyn Ther, 1 (2004) 27-42.

[6] O. Mazor, A. Brandis, V. Plaks, E. Neumark, V. Rosenbach-Belkin, Y. Salomon, A. Scherz, WST11, a novel water-soluble bacteriochlorophyll derivative; cellular uptake, pharmacokinetics, biodistribution and vascular-targeted photodynamic activity using melanoma tumors as a model, Photochem Photobiol, 81 (2005) 342-351.

[7] A. Brandis, O. Mazor, E. Neumark, V. Rosenbach-Belkin, Y. Salomon, A. Scherz, Novel watersoluble bacteriochlorophyll derivatives for vascular-targeted photodynamic therapy: synthesis, solubility, phototoxicity and the effect of serum proteins, Photochem Photobiol, 81 (2005) 983993.

[8] S.S. Taneja, J. Bennett, J. Coleman, R. Grubb, G. Andriole, R.E. Reiter, L. Marks, A.R. Azzouzi, M. Emberton, Final Results of a Phase I/II Multicenter Trial of WST11 Vascular Targeted Photodynamic Therapy for Hemi-Ablation of the Prostate in Men with Unilateral Low Risk Prostate Cancer Performed in the United States, J Urol, 196 (2016) 1096-1104.

[9] A. Noweski, A. Roosen, S. Lebdai, E. Barret, M. Emberton, F. Benzaghou, M. Apfelbeck, B. Gaillac, C. Gratzke, C. Stief, A.R. Azzouzi, Medium-term Follow-up of Vascular-targeted Photodynamic Therapy of Localized Prostate Cancer Using TOOKAD Soluble WST-11 (Phase II Trials), Eur Urol Focus, (2018).

[10] L.G. Arnaut, M.M. Pereira, J.M. Dabrowski, E.F. Silva, F.A. Schaberle, A.R. Abreu, L.B. Rocha, M.M. Barsan, K. Urbanska, G. Stochel, C.M. Brett, Photodynamic therapy efficacy enhanced by dynamics: the role of charge transfer and photostability in the selection of photosensitizers, Chemistry, 20 (2014) 5346-5357.

[11] R. Saavedra, L.B. Rocha, J.M. Dabrowski, L.G. Arnaut, Modulation of biodistribution, pharmacokinetics, and photosensitivity with the delivery vehicle of a bacteriochlorin photosensitizer for photodynamic therapy, ChemMedChem, 9 (2014) 390-398.

[12] L.B. Rocha, L.C. Gomes-da-Silva, J.M. Dabrowski, L.G. Arnaut, Elimination of primary tumours and control of metastasis with rationally designed bacteriochlorin photodynamic therapy regimens, European journal of cancer (Oxford, England : 1990), 51 (2015) 1822-1830.

[13] L.B. Rocha, F. Schaberle, J.M. Dabrowski, S. Simoes, L.G. Arnaut, Intravenous Single-Dose Toxicity of Redaporfin-Based Photodynamic Therapy in Rodents, Int J Mol Sci, 16 (2015) 2923629249.

[14] B. Pucelik, L.G. Arnaut, G. Stochel, J.M. Dabrowski, Design of Pluronic-Based Formulation for Enhanced Redaporfin-Photodynamic Therapy against Pigmented Melanoma, ACS Appl Mater Interfaces, 8 (2016) 22039-22055.

[15] L.L. Santos, J. Oliveira, E. Monteiro, J. Santos, C. Sarmento, Treatment of Head and Neck Cancer with Photodynamic Therapy with Redaporfin: A Clinical Case Report, Case Rep Oncol, 11 (2018) 769-776.

[16] D. Kessel, Subcellular Targeting as a Determinant of the Efficacy of Photodynamic Therapy, Photochem Photobiol, 93 (2017) 609-612.

[17] I. Moserova, J. Kralova, Role of ER stress response in photodynamic therapy: ROS generated in different subcellular compartments trigger diverse cell death pathways, PLoS One, 7 (2012) e32972. 
[18] D. Kessel, Subcellular targets for photodynamic therapy: implications for initiation of apoptosis and autophagy, J Natl Compr Canc Netw, 10 Suppl 2 (2012) S56-59.

[19] M. Krzykawska-Serda, J.M. Dabrowski, L.G. Arnaut, M. Szczygiel, K. Urbanska, G. Stochel, M. Elas, The role of strong hypoxia in tumors after treatment in the outcome of bacteriochlorin-based photodynamic therapy, Free Radic Biol Med, 73 (2014) 239-251.

[20] M. Broekgaarden, R. Weijer, T.M. van Gulik, M.R. Hamblin, M. Heger, Tumor cell survival pathways activated by photodynamic therapy: a molecular basis for pharmacological inhibition strategies, Cancer Metastasis Rev, 34 (2015) 643-690.

[21] K. Pakos-Zebrucka, I. Koryga, K. Mnich, M. Ljujic, A. Samali, A.M. Gorman, The integrated stress response, EMBO Rep, 17 (2016) 1374-1395.

[22] C. Hetz, The unfolded protein response: controlling cell fate decisions under ER stress and beyond, Nat Rev Mol Cell Biol, 13 (2012) 89-102.

[23] P. Pihan, A. Carreras-Sureda, C. Hetz, BCL-2 family: integrating stress responses at the ER to control cell demise, Cell Death Differ, 24 (2017) 1478-1487.

[24] M. Korbelik, Role of cell stress signaling networks in cancer cell death and antitumor immune response following proteotoxic injury inflicted by photodynamic therapy, Lasers Surg Med, 50 (2018) 491-498.

[25] C. Giorgi, S. Marchi, P. Pinton, The machineries, regulation and cellular functions of mitochondrial calcium, Nat Rev Mol Cell Biol, 19 (2018) 713-730.

[26] A. Carreras-Sureda, P. Pihan, C. Hetz, Calcium signaling at the endoplasmic reticulum: finetuning stress responses, Cell Calcium, 70 (2018) 24-31.

[27] R. Ritz, F. Roser, N. Radomski, W.S. Strauss, M. Tatagiba, A. Gharabaghi, Subcellular colocalization of hypericin with respect to endoplasmic reticulum and Golgi apparatus in glioblastoma cells, Anticancer Res, 28 (2008) 2033-2038.

[28] E. Buytaert, J.Y. Matroule, S. Durinck, P. Close, S. Kocanova, J.R. Vandenheede, P.A. de Witte, J. Piette, P. Agostinis, Molecular effectors and modulators of hypericin-mediated cell death in bladder cancer cells, Oncogene, 27 (2008) 1916-1929.

[29] T. Verfaillie, N. Rubio, A.D. Garg, G. Bultynck, R. Rizzuto, J.P. Decuypere, J. Piette, C. Linehan, S. Gupta, A. Samali, P. Agostinis, PERK is required at the ER-mitochondrial contact sites to convey apoptosis after ROS-based ER stress, Cell Death Differ, 19 (2012) 1880-1891.

[30] T. Verfaillie, A. van Vliet, A.D. Garg, M. Dewaele, N. Rubio, S. Gupta, P. de Witte, A. Samali, P. Agostinis, Pro-apoptotic signaling induced by photo-oxidative ER stress is amplified by Noxa, not Bim, Biochem Biophys Res Commun, 438 (2013) 500-506.

[31] E. Panzarini, V. Inguscio, L. Dini, Timing the multiple cell death pathways initiated by Rose Bengal acetate photodynamic therapy, Cell Death Dis, 2 (2011) e169.

[32] J. Zhu, S. Tian, K.T. Li, Q. Chen, Y. Jiang, H.D. Lin, L.H. Yu, D.Q. Bai, Inhibition of breast cancer cell growth by methyl pyropheophenylchlorin photodynamic therapy is mediated though endoplasmic reticulum stress-induced autophagy in vitro and vivo, Cancer Med, 7 (2018) 19081920.

[33] J. Chen, J.H. Huang, Z. Wang, X. Song, Z. Chen, Q. Zeng, X. Zhou, Z. Zuo, S. Zhao, X. Chen, J. Kang, Endoplasmic reticulum stress-mediated autophagy contributes to 5-ethylamino-9diethylaminobenzo[a]phenoselenazinium-mediated photodynamic therapy via the PERK-elF2alpha pathway, Onco Targets Ther, 11 (2018) 4315-4325.

[34] L.C. Gomes-da-Silva, L. Zhao, L.G. Arnaut, G. Kroemer, O. Kepp, Redaporfin induces immunogenic cell death by selective destruction of the endoplasmic reticulum and the Golgi apparatus, Oncotarget, 9 (2018) 31169-31170.

[35] L.C. Gomes-da-Silva, L. Zhao, L. Bezu, H. Zhou, A. Sauvat, P. Liu, S. Durand, M. Leduc, S. Souquere, F. Loos, L. Mondragon, B. Sveinbjornsson, O. Rekdal, G. Boncompain, F. Perez, L.G. 
Arnaut, O. Kepp, G. Kroemer, Photodynamic therapy with redaporfin targets the endoplasmic reticulum and Golgi apparatus, The EMBO journal, 37 (2018).

[36] W. Li, A.N. Kong, Molecular mechanisms of Nrf2-mediated antioxidant response, Mol Carcinog, 48 (2009) 91-104.

[37] S. Kocanova, E. Buytaert, J.Y. Matroule, J. Piette, J. Golab, P. de Witte, P. Agostinis, Induction of heme-oxygenase 1 requires the P38MAPK and PI3K pathways and suppresses apoptotic cell death following hypericin-mediated photodynamic therapy, Apoptosis, 12 (2007) 731-741. [38] D. Nowis, M. Legat, T. Grzela, J. Niderla, E. Wilczek, G.M. Wilczynski, E. Glodkowska, P. Mrowka, T. Issat, J. Dulak, A. Jozkowicz, H. Was, M. Adamek, A. Wrzosek, S. Nazarewski, M. Makowski, T. Stoklosa, M. Jakobisiak, J. Golab, Heme oxygenase-1 protects tumor cells against photodynamic therapy-mediated cytotoxicity, Oncogene, 25 (2006) 3365-3374.

[39] J. Frank, M.R. Lornejad-Schafer, H. Schoffl, A. Flaccus, C. Lambert, H.K. Biesalski, Inhibition of heme oxygenase-1 increases responsiveness of melanoma cells to ALA-based photodynamic therapy, Int J Oncol, 31 (2007) 1539-1545.

[40] T. Takahashi, S. Suzuki, S. Misawa, J. Akimoto, Y. Shinoda, Y. Fujiwara, Photodynamic therapy using talaporfin sodium induces heme oxygenase-1 expression in rat malignant meningioma KMY-J cells, The Journal of toxicological sciences, 43 (2018) 353-358.

[41] Y. Hagiya, T. Adachi, S. Ogura, R. An, A. Tamura, H. Nakagawa, I. Okura, T. Mochizuki, T. Ishikawa, Nrf2-dependent induction of human ABC transporter ABCG2 and heme oxygenase-1 in HepG2 cells by photoactivation of porphyrins: biochemical implications for cancer cell response to photodynamic therapy, J Exp Ther Oncol, 7 (2008) 153-167.

[42] T. Ishikawa, Y. Kajimoto, W. Sun, H. Nakagawa, Y. Inoue, Y. Ikegami, S. Miyatake, T. Kuroiwa, Role of Nrf2 in cancer photodynamic therapy: regulation of human $A B C$ transporter ABCG2, J Pharm Sci, 102 (2013) 3058-3069.

[43] B.H. Choi, I.G. Ryoo, H.C. Kang, M.K. Kwak, The sensitivity of cancer cells to pheophorbide abased photodynamic therapy is enhanced by Nrf2 silencing, PLoS One, 9 (2014) e107158.

[44] S. Tian, M. Yong, J. Zhu, L. Zhang, L. Pan, Q. Chen, K.T. Li, Y.H. Kong, Y. Jiang, T.H. Yu, L.H. Yu, D.Q. Bai, Enhancement of the Effect of Methyl Pyropheophorbide-a-Mediated Photodynamic Therapy was Achieved by Increasing ROS through Inhibition of Nrf2-HO-1 or Nrf2-ABCG2 Signaling, Anticancer Agents Med Chem, 17 (2017) 1824-1836.

[45] S.G. Kimani, J.B. Phillips, J.I. Bruce, A.J. MacRobert, J.P. Golding, Antioxidant Inhibitors Potentiate the Cytotoxicity of Photodynamic Therapy, Photochemistry and Photobiology, 88 (2012) 175-187.

[46] H.T. Soares, J.R.S. Campos, L.C. Gomes-da-Silva, F.A. Schaberle, J.M. Dabrowski, L.G. Arnaut, Pro-oxidant and Antioxidant Effects in Photodynamic Therapy: Cells Recognise that Not All Exogenous ROS Are Alike, ChemBioChem, 17 (2016) 836-842.

[47] K.E. Wright, A.J. MacRobert, J.B. Phillips, Inhibition of Specific Cellular Antioxidant Pathways Increases the Sensitivity of Neurons to Meta-tetrahydroxyphenyl Chlorin-Mediated Photodynamic Therapy in a 3D Co-culture Model, Photochemistry and Photobiology, 88 (2012) 1539-1545.

[48] J. Golab, D. Nowis, M. Skrzycki, H. Czeczot, A. Baranczyk-Kuzma, G.M. Wilczynski, M.

Makowski, P. Mroz, K. Kozar, R. Kaminski, A. Jalili, M. Kopec, T. Grzela, M. Jakobisiak, Antitumor effects of photodynamic therapy are potentiated by 2-methoxyestradiol. A superoxide dismutase inhibitor, The Journal of biological chemistry, 278 (2003) 407-414.

[49] F. Jiang, A.M. Robin, M. Katakowski, L. Tong, M. Espiritu, G. Singh, M. Chopp, Photodynamic therapy with photofrin in combination with Buthionine Sulfoximine (BSO) of human glioma in the nude rat, Lasers in Medical Science, 18 (2003) 128-133. 
[50] R. Bachor, M. Scholz, C.R. Shea, T. Hasan, Mechanism of Photosensitization by Microspherebound Chlorin e<sub $>6</$ sub $>$ in Human Bladder Carcinoma Cells, Cancer Research, 51 (1991) 4410-4414.

[51] A.C. Miller, B.W. Henderson, The Influence of Cellular Glutathione Content on Cell Survival Following Photodynamic Treatment in Vitro, Radiation Research, 107 (1986) 83-94.

[52] M. Price, S.R. Terlecky, D. Kessel, A Role for Hydrogen Peroxide in the Pro-apoptotic Effects of Photodynamic Therapy, Photochemistry and Photobiology, 85 (2009) 1491-1496.

[53] L. Galluzzi, I. Vitale, S.A. Aaronson, J.M. Abrams, D. Adam, P. Agostinis, E.S. Alnemri, L. Altucci, I. Amelio, D.W. Andrews, M. Annicchiarico-Petruzzelli, A.V. Antonov, E. Arama, E.H. Baehrecke, N.A. Barlev, N.G. Bazan, F. Bernassola, M.J.M. Bertrand, K. Bianchi, M.V. Blagosklonny, K. Blomgren, C. Borner, P. Boya, C. Brenner, M. Campanella, E. Candi, D. Carmona-Gutierrez, F. Cecconi, F.K. Chan, N.S. Chandel, E.H. Cheng, J.E. Chipuk, J.A. Cidlowski, A. Ciechanover, G.M. Cohen, M. Conrad, J.R. Cubillos-Ruiz, P.E. Czabotar, V. D'Angiolella, T.M. Dawson, V.L. Dawson, V. De Laurenzi, R. De Maria, K.M. Debatin, R.J. DeBerardinis, M. Deshmukh, N. Di Daniele, F. Di Virgilio, V.M. Dixit, S.J. Dixon, C.S. Duckett, B.D. Dynlacht, W.S. El-Deiry, J.W. Elrod, G.M. Fimia, S. Fulda, A.J. Garcia-Saez, A.D. Garg, C. Garrido, E. Gavathiotis, P. Golstein, E. Gottlieb, D.R. Green, L.A. Greene, H. Gronemeyer, A. Gross, G. Hajnoczky, J.M. Hardwick, I.S. Harris, M.O. Hengartner, C. Hetz, H. Ichijo, M. Jaattela, B. Joseph, P.J. Jost, P.P. Juin, W.J. Kaiser, M. Karin, T. Kaufmann, O. Kepp, A. Kimchi, R.N. Kitsis, D.J. Klionsky, R.A. Knight, S. Kumar, S.W. Lee, J.J. Lemasters, B. Levine, A. Linkermann, S.A. Lipton, R.A. Lockshin, C. Lopez-Otin, S.W. Lowe, T. Luedde, E. Lugli, M. MacFarlane, F. Madeo, M. Malewicz, W. Malorni, G. Manic, J.C. Marine, S.J. Martin, J.C. Martinou, J.P. Medema, P. Mehlen, P. Meier, S. Melino, E.A. Miao, J.D. Molkentin, U.M. Moll, C. MunozPinedo, S. Nagata, G. Nunez, A. Oberst, M. Oren, M. Overholtzer, M. Pagano, T. Panaretakis, M. Pasparakis, J.M. Penninger, D.M. Pereira, S. Pervaiz, M.E. Peter, M. Piacentini, P. Pinton, J.H.M. Prehn, H. Puthalakath, G.A. Rabinovich, M. Rehm, R. Rizzuto, C.M.P. Rodrigues, D.C. Rubinsztein, T. Rudel, K.M. Ryan, E. Sayan, L. Scorrano, F. Shao, Y. Shi, J. Silke, H.U. Simon, A. Sistigu, B.R. Stockwell, A. Strasser, G. Szabadkai, S.W.G. Tait, D. Tang, N. Tavernarakis, A. Thorburn, Y. Tsujimoto, B. Turk, T. Vanden Berghe, P. Vandenabeele, M.G. Vander Heiden, A. Villunger, H.W. Virgin, K.H. Vousden, D. Vucic, E.F. Wagner, H. Walczak, D. Wallach, Y. Wang, J.A. Wells, W. Wood, J. Yuan, Z. Zakeri, B. Zhivotovsky, L. Zitvogel, G. Melino, G. Kroemer, Molecular mechanisms of cell death: recommendations of the Nomenclature Committee on Cell Death 2018, Cell Death Differ, 25 (2018) 486-541.

[54] D. Kessel, N.L. Oleinick, Cell Death Pathways Associated with Photodynamic Therapy: An Update, Photochem Photobiol, 94 (2018) 213-218.

[55] J. Soriano, I. Mora-Espi, M.E. Alea-Reyes, L. Perez-Garcia, L. Barrios, E. Ibanez, C. Nogues, Cell Death Mechanisms in Tumoral and Non-Tumoral Human Cell Lines Triggered by Photodynamic Treatments: Apoptosis, Necrosis and Parthanatos, Sci Rep, 7 (2017) 41340.

[56] M. Sun, C. Zhou, H. Zeng, N. Puebla-Osorio, E. Damiani, J. Chen, H. Wang, G. Li, F. Yin, L. Shan, D. Zuo, Y. Liao, Z. Wang, L. Zheng, Y. Hua, Z. Cai, Hiporfin-mediated photodynamic therapy in preclinical treatment of osteosarcoma, Photochem Photobiol, 91 (2015) 533-544.

[57] Y. Miki, J. Akimoto, K. Moritake, C. Hironaka, Y. Fujiwara, Photodynamic therapy using talaporfin sodium induces concentration-dependent programmed necroptosis in human glioblastoma T98G cells, Lasers Med Sci, 30 (2015) 1739-1745.

[58] J. Piette, Signalling pathway activation by photodynamic therapy: NF-kappaB at the crossroad between oncology and immunology, Photochem Photobiol Sci, 14 (2015) 1510-1517.

[59] P. Mroz, A. Yaroslavsky, G.B. Kharkwal, M.R. Hamblin, Cell death pathways in photodynamic therapy of cancer, Cancers (Basel), 3 (2011) 2516-2539. 
[60] P. Syntichaki, N. Tavernarakis, Death by necrosis. Uncontrollable catastrophe, or is there order behind the chaos?, EMBO Rep, 3 (2002) 604-609.

[61] K.F. Ferri, G. Kroemer, Organelle-specific initiation of cell death pathways, Nat Cell Biol, 3 (2001) E255-263.

[62] S.L. Fink, B.T. Cookson, Apoptosis, pyroptosis, and necrosis: mechanistic description of dead and dying eukaryotic cells, Infect Immun, 73 (2005) 1907-1916.

[63] W. Luo, R.S. Liu, J.G. Zhu, Y.C. Li, H.C. Liu, Subcellular location and photodynamic therapeutic effect of chlorin e6 in the human tongue squamous cell cancer Tca8113 cell line, Oncol Lett, 9 (2015) 551-556.

[64] K. Plaetzer, T. Kiesslich, B. Krammer, P. Hammerl, Characterization of the cell death modes and the associated changes in cellular energy supply in response to AIPcS4-PDT, Photochem Photobiol Sci, 1 (2002) 172-177.

[65] Y. Miki, J. Akimoto, M. Hiranuma, Y. Fujiwara, Effect of talaporfin sodium-mediated photodynamic therapy on cell death modalities in human glioblastoma T98G cells, J Toxicol Sci, 39 (2014) 821-827.

[66] M. Dellinger, Apoptosis or necrosis following Photofrin photosensitization: influence of the incubation protocol, Photochem Photobiol, 64 (1996) 182-187.

[67] Y.J. Hsieh, C.C. Wu, C.J. Chang, J.S. Yu, Subcellular localization of Photofrin determines the death phenotype of human epidermoid carcinoma A431 cells triggered by photodynamic therapy: when plasma membranes are the main targets, J Cell Physiol, 194 (2003) 363-375.

[68] C. Fabris, G. Valduga, G. Miotto, L. Borsetto, G. Jori, S. Garbisa, E. Reddi, Photosensitization with zinc (II) phthalocyanine as a switch in the decision between apoptosis and necrosis, Cancer Res, 61 (2001) 7495-7500.

[69] S.A. Thompson, A. Aggarwal, S. Singh, A.P. Adam, J.P.C. Tome, C.M. Drain, Compromising the plasma membrane as a secondary target in photodynamic therapy-induced necrosis, Bioorganic \& Medicinal Chemistry, 26 (2018) 5224-5228.

[70] T. Vanden Berghe, A. Linkermann, S. Jouan-Lanhouet, H. Walczak, P. Vandenabeele, Regulated necrosis: the expanding network of non-apoptotic cell death pathways, Nature reviews. Molecular cell biology, 15 (2014) 135-147.

[71] D. Tang, R. Kang, T.V. Berghe, P. Vandenabeele, G. Kroemer, The molecular machinery of regulated cell death, Cell Research, 29 (2019) 347-364.

[72] G. Fettweis, E. Di Valentin, L. L'Homme, C. Lassence, F. Dequiedt, M. Fillet, I. Coupienne, J. Piette, RIP3 antagonizes a TSC2-mediated pro-survival pathway in glioblastoma cell death, Biochimica et biophysica acta. Molecular cell research, 1864 (2017) 113-124.

[73] I. Coupienne, G. Fettweis, N. Rubio, P. Agostinis, J. Piette, 5-ALA-PDT induces RIP3-dependent necrosis in glioblastoma, Photochemical \& photobiological sciences : Official journal of the European Photochemistry Association and the European Society for Photobiology, 10 (2011) 18681878.

[74] Y. Fuchs, H. Steller, Live to die another way: modes of programmed cell death and the signals emanating from dying cells, Nat Rev Mol Cell Biol, 16 (2015) 329-344.

[75] C.F.A. Warren, M.W. Wong-Brown, N.A. Bowden, BCL-2 family isoforms in apoptosis and cancer, Cell Death Dis, 10 (2019) 177.

[76] X.Y. Shen, N. Zacal, G. Singh, A.J. Rainbow, Alterations in mitochondrial and apoptosisregulating gene expression in photodynamic therapy-resistant variants of HT29 colon carcinoma cells, Photochem Photobiol, 81 (2005) 306-313.

[77] S. Karmakar, N.L. Banik, S.J. Patel, S.K. Ray, 5-Aminolevulinic acid-based photodynamic therapy suppressed survival factors and activated proteases for apoptosis in human glioblastoma U87MG cells, Neurosci Lett, 415 (2007) 242-247. 
[78] L.Y. Xue, S.M. Chiu, N.L. Oleinick, Photochemical destruction of the Bcl-2 oncoprotein during photodynamic therapy with the phthalocyanine photosensitizer Pc 4, Oncogene, 20 (2001) 34203427.

[79] M. Srivastava, N. Ahmad, S. Gupta, H. Mukhtar, Involvement of Bcl-2 and Bax in photodynamic therapy-mediated apoptosis. Antisense Bcl-2 oligonucleotide sensitizes RIF 1 cells to photodynamic therapy apoptosis, J Biol Chem, 276 (2001) 15481-15488.

[80] D. Kessel, M. Castelli, Evidence that bcl-2 is the target of three photosensitizers that induce a rapid apoptotic response, Photochem Photobiol, 74 (2001) 318-322.

[81] S. Rello-Varona, J.C. Stockert, M. Canete, P. Acedo, A. Villanueva, Mitotic catastrophe induced in HeLa cells by photodynamic treatment with Zn(II)-phthalocyanine, Int J Oncol, 32 (2008) 11891196.

[82] J. Koval, J. Mikes, R. Jendzelovsky, M. Kello, P. Solar, P. Fedorocko, Degradation of HER2 receptor through hypericin-mediated photodynamic therapy, Photochem Photobiol, 86 (2010) 200-205.

[83] E. Buytaert, G. Callewaert, J.R. Vandenheede, P. Agostinis, Deficiency in apoptotic effectors Bax and Bak reveals an autophagic cell death pathway initiated by photodamage to the endoplasmic reticulum, Autophagy, 2 (2006) 238-240.

[84] E. Hensel, S. Hensel, R. Sielaff, [Frequency and localization of facets in adults with correct dental arches and malocclusion in anterior teeth region regarding periodontal reaction and occlusal guidance], Stomatol DDR, 40 (1990) 232-235.

[85] E. Buytaert, G. Callewaert, N. Hendrickx, L. Scorrano, D. Hartmann, L. Missiaen, J.R. Vandenheede, I. Heirman, J. Grooten, P. Agostinis, Role of endoplasmic reticulum depletion and multidomain proapoptotic $B A X$ and BAK proteins in shaping cell death after hypericin-mediated photodynamic therapy, FASEB J, 20 (2006) 756-758.

[86] C. Fidanzi-Dugas, B. Liagre, G. Chemin, A. Perraud, C. Carrion, C.Y. Couquet, R. Granet, V. Sol, D.Y. Leger, Analysis of the in vitro and in vivo effects of photodynamic therapy on prostate cancer by using new photosensitizers, protoporphyrin IX-polyamine derivatives, Biochimica et biophysica acta. General subjects, 1861 (2017) 1676-1690.

[87] D.J. Klionsky, K. Abdelmohsen, A. Abe, M.J. Abedin, H. Abeliovich, A. Acevedo Arozena, H. Adachi, C.M. Adams, P.D. Adams, K. Adeli, P.J. Adhihetty, S.G. Adler, G. Agam, R. Agarwal, M.K. Aghi, M. Agnello, P. Agostinis, P.V. Aguilar, J. Aguirre-Ghiso, E.M. Airoldi, S. Ait-Si-Ali, T. Akematsu, E.T. Akporiaye, M. Al-Rubeai, G.M. Albaiceta, C. Albanese, D. Albani, M.L. Albert, J. Aldudo, H. Algul, M. Alirezaei, I. Alloza, A. Almasan, M. Almonte-Beceril, E.S. Alnemri, C. Alonso, N. AltanBonnet, D.C. Altieri, S. Alvarez, L. Alvarez-Erviti, S. Alves, G. Amadoro, A. Amano, C. Amantini, S. Ambrosio, I. Amelio, A.O. Amer, M. Amessou, A. Amon, Z. An, F.A. Anania, S.U. Andersen, U.P. Andley, C.K. Andreadi, N. Andrieu-Abadie, A. Anel, D.K. Ann, S. Anoopkumar-Dukie, M. Antonioli, H. Aoki, N. Apostolova, S. Aquila, K. Aquilano, K. Araki, E. Arama, A. Aranda, J. Araya, A. Arcaro, E. Arias, H. Arimoto, A.R. Ariosa, J.L. Armstrong, T. Arnould, I. Arsov, K. Asanuma, V. Askanas, E. Asselin, R. Atarashi, S.S. Atherton, J.D. Atkin, L.D. Attardi, P. Auberger, G. Auburger, L. Aurelian, R. Autelli, L. Avagliano, M.L. Avantaggiati, L. Avrahami, S. Awale, N. Azad, T. Bachetti, J.M. Backer, D.H. Bae, J.S. Bae, O.N. Bae, S.H. Bae, E.H. Baehrecke, S.H. Baek, S. Baghdiguian, A. BagniewskaZadworna, H. Bai, J. Bai, X.Y. Bai, Y. Bailly, K.N. Balaji, W. Balduini, A. Ballabio, R. Balzan, R. Banerjee, G. Banhegyi, H. Bao, B. Barbeau, M.D. Barrachina, E. Barreiro, B. Bartel, A. Bartolome, D.C. Bassham, M.T. Bassi, R.C. Bast, Jr., A. Basu, M.T. Batista, H. Batoko, M. Battino, K. Bauckman, B.L. Baumgarner, K.U. Bayer, R. Beale, J.F. Beaulieu, G.R. Beck, Jr., C. Becker, J.D. Beckham, P.A. Bedard, P.J. Bednarski, T.J. Begley, C. Behl, C. Behrends, G.M. Behrens, K.E. Behrns, E. Bejarano, A. Belaid, F. Belleudi, G. Benard, G. Berchem, D. Bergamaschi, M. Bergami, B. Berkhout, L. Berliocchi, A. Bernard, M. Bernard, F. Bernassola, A. Bertolotti, A.S. Bess, S. Besteiro, S. Bettuzzi, S. Bhalla, S. 
Bhattacharyya, S.K. Bhutia, C. Biagosch, M.W. Bianchi, M. Biard-Piechaczyk, V. Billes, C. Bincoletto, B. Bingol, S.W. Bird, M. Bitoun, I. Bjedov, C. Blackstone, L. Blanc, G.A. Blanco, H.K. Blomhoff, E. Boada-Romero, S. Bockler, M. Boes, K. Boesze-Battaglia, L.H. Boise, A. Bolino, A. Boman, P. Bonaldo, M. Bordi, J. Bosch, L.M. Botana, J. Botti, G. Bou, M. Bouche, M. Bouchecareilh, M.J. Boucher, M.E. Boulton, S.G. Bouret, P. Boya, M. Boyer-Guittaut, P.V. Bozhkov, N. Brady, V.M. Braga, C. Brancolini, G.H. Braus, J.M. Bravo-San Pedro, L.A. Brennan, E.H. Bresnick, P. Brest, D. Bridges, M.A. Bringer, M. Brini, G.C. Brito, B. Brodin, P.S. Brookes, E.J. Brown, K. Brown, H.E. Broxmeyer, A. Bruhat, P.C. Brum, J.H. Brumell, N. Brunetti-Pierri, R.J. Bryson-Richardson, S. Buch, A.M. Buchan, H. Budak, D.V. Bulavin, S.J. Bultman, G. Bultynck, V. Bumbasirevic, Y. Burelle, R.E. Burke, M. Burmeister, P. Butikofer, L. Caberlotto, K. Cadwell, M. Cahova, D. Cai, J. Cai, Q. Cai, S. Calatayud, N. Camougrand, M. Campanella, G.R. Campbell, M. Campbell, S. Campello, R. Candau, I. Caniggia, L. Cantoni, L. Cao, A.B. Caplan, M. Caraglia, C. Cardinali, S.M. Cardoso, J.S. Carew, L.A. Carleton, C.R. Carlin, S. Carloni, S.R. Carlsson, D. Carmona-Gutierrez, L.A. Carneiro, O. Carnevali, S. Carra, A. Carrier, B. Carroll, C. Casas, J. Casas, G. Cassinelli, P. Castets, S. Castro-Obregon, G. Cavallini, I. Ceccherini, F. Cecconi, A.I. Cederbaum, V. Cena, S. Cenci, C. Cerella, D. Cervia, S. Cetrullo, H. Chaachouay, H.J. Chae, A.S. Chagin, C.Y. Chai, G. Chakrabarti, G. Chamilos, E.Y. Chan, M.T. Chan, D. Chandra, P. Chandra, C.P. Chang, R.C. Chang, T.Y. Chang, J.C. Chatham, S. Chatterjee, S. Chauhan, Y. Che, M.E. Cheetham, R. Cheluvappa, C.J. Chen, G. Chen, G.C. Chen, G. Chen, H. Chen, J.W. Chen, J.K. Chen, M. Chen, M. Chen, P. Chen, Q. Chen, Q. Chen, S.D. Chen, S. Chen, S.S. Chen, W. Chen, W.J. Chen, W.Q. Chen, W. Chen, X. Chen, Y.H. Chen, Y.G. Chen, Y. Chen, Y. Chen, Y. Chen, Y.J. Chen, Y.Q. Chen, Y. Chen, Z. Chen, Z. Chen, A. Cheng, C.H. Cheng, H. Cheng, H. Cheong, S. Cherry, J. Chesney, C.H. Cheung, E. Chevet, H.C. Chi, S.G. Chi, F. Chiacchiera, H.L. Chiang, R. Chiarelli, M. Chiariello, M. Chieppa, L.S. Chin, M. Chiong, G.N. Chiu, D.H. Cho, S.G. Cho, W.C. Cho, Y.Y. Cho, Y.S. Cho, A.M. Choi, E.J. Choi, E.K. Choi, J. Choi, M.E. Choi, S.I. Choi, T.F. Chou, S. Chouaib, D. Choubey, V. Choubey, K.C. Chow, K. Chowdhury, C.T. Chu, T.H. Chuang, T. Chun, H. Chung, T. Chung, Y.L. Chung, Y.J. Chwae, V. Cianfanelli, R. Ciarcia, I.A. Ciechomska, M.R. Ciriolo, M. Cirone, S. Claerhout, M.J. Clague, J. Claria, P.G. Clarke, R. Clarke, E. Clementi, C. Cleyrat, M. Cnop, E.M. Coccia, T. Cocco, P. Codogno, J. Coers, E.E. Cohen, D. Colecchia, L. Coletto, N.S. Coll, E. ColucciGuyon, S. Comincini, M. Condello, K.L. Cook, G.H. Coombs, C.D. Cooper, J.M. Cooper, I. Coppens, M.T. Corasaniti, M. Corazzari, R. Corbalan, E. Corcelle-Termeau, M.D. Cordero, C. Corral-Ramos, O. Corti, A. Cossarizza, P. Costelli, S. Costes, S.L. Cotman, A. Coto-Montes, S. Cottet, E. Couve, L.R. Covey, L.A. Cowart, J.S. Cox, F.P. Coxon, C.B. Coyne, M.S. Cragg, R.J. Craven, T. Crepaldi, J.L. Crespo, A. Criollo, V. Crippa, M.T. Cruz, A.M. Cuervo, J.M. Cuezva, T. Cui, P.R. Cutillas, M.J. Czaja, M.F. Czyzyk-Krzeska, R.K. Dagda, U. Dahmen, C. Dai, W. Dai, Y. Dai, K.N. Dalby, L. Dalla Valle, G. Dalmasso, M. D'Amelio, M. Damme, A. Darfeuille-Michaud, C. Dargemont, V.M. Darley-Usmar, S. Dasarathy, B. Dasgupta, S. Dash, C.R. Dass, H.M. Davey, L.M. Davids, D. Davila, R.J. Davis, T.M. Dawson, V.L. Dawson, P. Daza, J. de Belleroche, P. de Figueiredo, R.C. de Figueiredo, J. de la Fuente, L. De Martino, A. De Matteis, G.R. De Meyer, A. De Milito, M. De Santi, W. de Souza, V. De Tata, D. De Zio, J. Debnath, R. Dechant, J.P. Decuypere, S. Deegan, B. Dehay, B. Del Bello, D.P. Del Re, R. Delage-Mourroux, L.M. Delbridge, L. Deldicque, E. Delorme-Axford, Y. Deng, J. Dengjel, M. Denizot, P. Dent, C.J. Der, V. Deretic, B. Derrien, E. Deutsch, T.P. Devarenne, R.J. Devenish, S. Di Bartolomeo, N. Di Daniele, F. Di Domenico, A. Di Nardo, S. Di Paola, A. Di Pietro, L. Di Renzo, A. DiAntonio, G. Diaz-Araya, I. Diaz-Laviada, M.T. Diaz-Meco, J. Diaz-Nido, C.A. Dickey, R.C. Dickson, M. Diederich, P. Digard, I. Dikic, S.P. Dinesh-Kumar, C. Ding, W.X. Ding, Z. Ding, L. Dini, J.H. Distler, A. Diwan, M. Djavaheri-Mergny, K. Dmytruk, R.C. Dobson, V. Doetsch, K. Dokladny, S. Dokudovskaya, M. Donadelli, X.C. Dong, X. Dong, Z. Dong, T.M. Donohue, Jr., K.S. Doran, G. D'Orazi, G.W. Dorn, 2nd, V. Dosenko, S. Dridi, L. Drucker, J. Du, L.L. Du, L. Du, A. du Toit, P. Dua, L. Duan, P. Duann, V.K. Dubey, M.R. Duchen, M.A. Duchosal, H. Duez, I. Dugail, V.I. Dumit, M.C. 
Duncan, E.A. Dunlop, W.A. Dunn, Jr., N. Dupont, L. Dupuis, R.V. Duran, T.M. Durcan, S. DuvezinCaubet, U. Duvvuri, V. Eapen, D. Ebrahimi-Fakhari, A. Echard, L. Eckhart, C.L. Edelstein, A.L. Edinger, L. Eichinger, T. Eisenberg, A. Eisenberg-Lerner, N.T. Eissa, W.S. El-Deiry, V. El-Khoury, Z. Elazar, H. Eldar-Finkelman, C.J. Elliott, E. Emanuele, U. Emmenegger, N. Engedal, A.M. Engelbrecht, S. Engelender, J.M. Enserink, R. Erdmann, J. Erenpreisa, R. Eri, J.L. Eriksen, A. Erman, R. Escalante, E.L. Eskelinen, L. Espert, L. Esteban-Martinez, T.J. Evans, M. Fabri, G. Fabrias, C. Fabrizi, A. Facchiano, N.J. Faergeman, A. Faggioni, W.D. Fairlie, C. Fan, D. Fan, J. Fan, S. Fang, M. Fanto, A. Fanzani, T. Farkas, M. Faure, F.B. Favier, H. Fearnhead, M. Federici, E. Fei, T.C. Felizardo, H. Feng, Y. Feng, Y. Feng, T.A. Ferguson, A.F. Fernandez, M.G. Fernandez-Barrena, J.C. Fernandez-Checa, A. Fernandez-Lopez, M.E. Fernandez-Zapico, O. Feron, E. Ferraro, C.V. Ferreira-Halder, L. Fesus, R. Feuer, F.C. Fiesel, E.C. Filippi-Chiela, G. Filomeni, G.M. Fimia, J.H. Fingert, S. Finkbeiner, T. Finkel, F. Fiorito, P.B. Fisher, M. Flajolet, F. Flamigni, O. Florey, S. Florio, R.A. Floto, M. Folini, C. Follo, E.A. Fon, F. Fornai, F. Fortunato, A. Fraldi, R. Franco, A. Francois, A. Francois, L.B. Frankel, I.D. Fraser, N. Frey, D.G. Freyssenet, C. Frezza, S.L. Friedman, D.E. Frigo, D. Fu, J.M. Fuentes, J. Fueyo, Y. Fujitani, Y. Fujiwara, M. Fujiya, M. Fukuda, S. Fulda, C. Fusco, B. Gabryel, M. Gaestel, P. Gailly, M. Gajewska, S. Galadari, G. Galili, I. Galindo, M.F. Galindo, G. Galliciotti, L. Galluzzi, L. Galluzzi, V. Galy, N. Gammoh, S. Gandy, A.K. Ganesan, S. Ganesan, I.G. Ganley, M. Gannage, F.B. Gao, F. Gao, J.X. Gao, L. Garcia Nannig, E. Garcia Vescovi, M. Garcia-Macia, C. Garcia-Ruiz, A.D. Garg, P.K. Garg, R. Gargini, N.C. Gassen, D. Gatica, E. Gatti, J. Gavard, E. Gavathiotis, L. Ge, P. Ge, S. Ge, P.W. Gean, V. Gelmetti, A.A. Genazzani, J. Geng, P. Genschik, L. Gerner, J.E. Gestwicki, D.A. Gewirtz, S. Ghavami, E. Ghigo, D. Ghosh, A.M. Giammarioli, F. Giampieri, C. Giampietri, A. Giatromanolaki, D.J. Gibbings, L. Gibellini, S.B. Gibson, V. Ginet, A. Giordano, F. Giorgini, E. Giovannetti, S.E. Girardin, S. Gispert, S. Giuliano, C.L. Gladson, A. Glavic, M. Gleave, N. Godefroy, R.M. Gogal, Jr., K. Gokulan, G.H. Goldman, D. Goletti, M.S. Goligorsky, A.V. Gomes, L.C. Gomes, H. Gomez, C. Gomez-Manzano, R. Gomez-Sanchez, D.A. Goncalves, E. Goncu, Q. Gong, C. Gongora, C.B. Gonzalez, P. Gonzalez-Alegre, P. Gonzalez-Cabo, R.A. Gonzalez-Polo, I.S. Goping, C. Gorbea, N.V. Gorbunov, D.R. Goring, A.M. Gorman, S.M. Gorski, S. Goruppi, S. Goto-Yamada, C. Gotor, R.A. Gottlieb, I. Gozes, D. Gozuacik, Y. Graba, M. Graef, G.E. Granato, G.D. Grant, S. Grant, G.L. Gravina, D.R. Green, A. Greenhough, M.T. Greenwood, B. Grimaldi, F. Gros, C. Grose, J.F. Groulx, F. Gruber, P. Grumati, T. Grune, J.L. Guan, K.L. Guan, B. Guerra, C. Guillen, K. Gulshan, J. Gunst, C. Guo, L. Guo, M. Guo, W. Guo, X.G. Guo, A.A. Gust, A.B. Gustafsson, E. Gutierrez, M.G. Gutierrez, H.S. Gwak, A. Haas, J.E. Haber, S. Hadano, M. Hagedorn, D.R. Hahn, A.J. Halayko, A. Hamacher-Brady, K. Hamada, A. Hamai, A. Hamann, M. Hamasaki, I. Hamer, Q. Hamid, E.M. Hammond, F. Han, W. Han, J.T. Handa, J.A. Hanover, M. Hansen, M. Harada, L. Harhaji-Trajkovic, J.W. Harper, A.H. Harrath, A.L. Harris, J. Harris, U. Hasler, P. Hasselblatt, K. Hasui, R.G. Hawley, T.S. Hawley, C. He, C.Y. He, F. He, G. He, R.R. He, X.H. He, Y.W. He, Y.Y. He, J.K. Heath, M.J. Hebert, R.A. Heinzen, G.V. Helgason, M. Hensel, E.P. Henske, C. Her, P.K. Herman, A. Hernandez, C. Hernandez, S. Hernandez-Tiedra, C. Hetz, P.R. Hiesinger, K. Higaki, S. Hilfiker, B.G. Hill, J.A. Hill, W.D. Hill, K. Hino, D. Hofius, P. Hofman, G.U. Hoglinger, J. Hohfeld, M.K. Holz, Y. Hong, D.A. Hood, J.J. Hoozemans, T. Hoppe, C. Hsu, C.Y. Hsu, L.C. Hsu, D. Hu, G. Hu, H.M. Hu, H. Hu, M.C. Hu, Y.C. Hu, Z.W. Hu, F. Hua, Y. Hua, C. Huang, H.L. Huang, K.H. Huang, K.Y. Huang, S. Huang, S. Huang, W.P. Huang, Y.R. Huang, Y. Huang, Y. Huang, T.B. Huber, P. Huebbe, W.K. Huh, J.J. Hulmi, G.M. Hur, J.H. Hurley, Z. Husak, S.N. Hussain, S. Hussain, J.J. Hwang, S. Hwang, T.I. Hwang, A. Ichihara, Y. Imai, C. Imbriano, M. Inomata, T. Into, V. Iovane, J.L. Iovanna, R.V. Iozzo, N.Y. Ip, J.E. Irazoqui, P. Iribarren, Y. Isaka, A.J. Isakovic, H. Ischiropoulos, J.S. Isenberg, M. Ishaq, H. Ishida, I. Ishii, J.E. Ishmael, C. Isidoro, K. Isobe, E. Isono, S. Issazadeh-Navikas, K. Itahana, E. Itakura, A.I. Ivanov, A.K. Iyer, J.M. Izquierdo, Y. Izumi, V. Izzo, M. Jaattela, N. Jaber, D.J. Jackson, W.T. Jackson, T.G. Jacob, T.S. Jacques, C. Jagannath, A. Jain, N.R. Jana, B.K. Jang, A. Jani, B. Janji, P.R. Jannig, P.J. Jansson, S. Jean, M. Jendrach, J.H. Jeon, N. Jessen, E.B. Jeung, K. Jia, L. Jia, H. 
Jiang, H. Jiang, L. Jiang, T. Jiang, X. Jiang, X. Jiang, X. Jiang, Y. Jiang, Y. Jiang, A. Jimenez, C. Jin, H. Jin, L. Jin, M. Jin, S. Jin, U.K. Jinwal, E.K. Jo, T. Johansen, D.E. Johnson, G.V. Johnson, J.D. Johnson, E. Jonasch, C. Jones, L.A. Joosten, J. Jordan, A.M. Joseph, B. Joseph, A.M. Joubert, D. Ju, J. Ju, H.F. Juan, K. Juenemann, G. Juhasz, H.S. Jung, J.U. Jung, Y.K. Jung, H. Jungbluth, M.J. Justice, B. Jutten, N.O. Kaakoush, K. Kaarniranta, A. Kaasik, T. Kabuta, B. Kaeffer, K. Kagedal, A. Kahana, S. Kajimura, O. Kakhlon, M. Kalia, D.V. Kalvakolanu, Y. Kamada, K. Kambas, V.O. Kaminskyy, H.H. Kampinga, M. Kandouz, C. Kang, R. Kang, T.C. Kang, T. Kanki, T.D. Kanneganti, H. Kanno, A.G. Kanthasamy, M. Kantorow, M. Kaparakis-Liaskos, O. Kapuy, V. Karantza, M.R. Karim, P. Karmakar, A. Kaser, S. Kaushik, T. Kawula, A.M. Kaynar, P.Y. Ke, Z.J. Ke, J.H. Kehrl, K.E. Keller, J.K. Kemper, A.K. Kenworthy, O. Kepp, A. Kern, S. Kesari, D. Kessel, R. Ketteler, C. Kettelhut Ido, B. Khambu, M.M. Khan, V.K. Khandelwal, S. Khare, J.G. Kiang, A.A. Kiger, A. Kihara, A.L. Kim, C.H. Kim, D.R. Kim, D.H. Kim, E.K. Kim, H.Y. Kim, H.R. Kim, J.S. Kim, J.H. Kim, J.C. Kim, J.H. Kim, K.W. Kim, M.D. Kim, M.M. Kim, P.K. Kim, S.W. Kim, S.Y. Kim, Y.S. Kim, Y. Kim, A. Kimchi, A.C. Kimmelman, T. Kimura, J.S. King, K. Kirkegaard, V. Kirkin, L.A. Kirshenbaum, S. Kishi, Y. Kitajima, K. Kitamoto, Y. Kitaoka, K. Kitazato, R.A. Kley, W.T. Klimecki, M. Klinkenberg, J. Klucken, H. Knaevelsrud, E. Knecht, L. Knuppertz, J.L. Ko, S. Kobayashi, J.C. Koch, C. Koechlin-Ramonatxo, U. Koenig, Y.H. Koh, K. Kohler, S.D. Kohlwein, M. Koike, M. Komatsu, E. Kominami, D. Kong, H.J. Kong, E.G. Konstantakou, B.T. Kopp, T. Korcsmaros, L. Korhonen, V.I. Korolchuk, N.V. Koshkina, Y. Kou, M.I. Koukourakis, C. Koumenis, A.L. Kovacs, T. Kovacs, W.J. Kovacs, D. Koya, C. Kraft, D. Krainc, H. Kramer, T. Kravic-Stevovic, W. Krek, C. Kretz-Remy, R. Krick, M. Krishnamurthy, J. Kriston-Vizi, G. Kroemer, M.C. Kruer, R. Kruger, N.T. Ktistakis, K. Kuchitsu, C. Kuhn, A.P. Kumar, A. Kumar, A. Kumar, D. Kumar, D. Kumar, R. Kumar, S. Kumar, M. Kundu, H.J. Kung, A. Kuno, S.H. Kuo, J. Kuret, T. Kurz, T. Kwok, T.K. Kwon, Y.T. Kwon, I. Kyrmizi, A.R. La Spada, F. Lafont, T. Lahm, A. Lakkaraju, T. Lam, T. Lamark, S. Lancel, T.H. Landowski, D.J. Lane, J.D. Lane, C. Lanzi, P. Lapaquette, L.R. Lapierre, J. Laporte, J. Laukkarinen, G.W. Laurie, S. Lavandero, L. Lavie, M.J. LaVoie, B.Y. Law, H.K. Law, K.B. Law, R. Layfield, P.A. Lazo, L. Le Cam, K.G. Le Roch, H. Le Stunff, V. Leardkamolkarn, M. Lecuit, B.H. Lee, C.H. Lee, E.F. Lee, G.M. Lee, H.J. Lee, H. Lee, J.K. Lee, J. Lee, J.H. Lee, J.H. Lee, M. Lee, M.S. Lee, P.J. Lee, S.W. Lee, S.J. Lee, S.J. Lee, S.Y. Lee, S.H. Lee, S.S. Lee, S.J. Lee, S. Lee, Y.R. Lee, Y.J. Lee, Y.H. Lee, C. Leeuwenburgh, S. Lefort, R. Legouis, J. Lei, Q.Y. Lei, D.A. Leib, G. Leibowitz, I. Lekli, S.D. Lemaire, J.J. Lemasters, M.K. Lemberg, A. Lemoine, S. Leng, G. Lenz, P. Lenzi, L.O. Lerman, D. Lettieri Barbato, J.I. Leu, H.Y. Leung, B. Levine, P.A. Lewis, F. Lezoualc'h, C. Li, F. Li, F.J. Li, J. Li, K. Li, L. Li, M. Li, M. Li, Q. Li, R. Li, S. Li, W. Li, W. Li, X. Li, Y. Li, J. Lian, C. Liang, Q. Liang, Y. Liao, J. Liberal, P.P. Liberski, P. Lie, A.P. Lieberman, H.J. Lim, K.L. Lim, K. Lim, R.T. Lima, C.S. Lin, C.F. Lin, F. Lin, F. Lin, F.C. Lin, K. Lin, K.H. Lin, P.H. Lin, T. Lin, W.W. Lin, Y.S. Lin, Y. Lin, R. Linden, D. Lindholm, L.M. Lindqvist, P. Lingor, A. Linkermann, L.A. Liotta, M.M. Lipinski, V.A. Lira, M.P. Lisanti, P.B. Liton, B. Liu, C. Liu, C.F. Liu, F. Liu, H.J. Liu, J. Liu, J.J. Liu, J.L. Liu, K. Liu, L. Liu, L. Liu, Q. Liu, R.Y. Liu, S. Liu, S. Liu, W. Liu, X.D. Liu, X. Liu, X.H. Liu, X. Liu, X. Liu, X. Liu, Y. Liu, Y. Liu, Z. Liu, Z. Liu, J.P. Liuzzi, G. Lizard, M. Ljujic, I.J. Lodhi, S.E. Logue, B.L. Lokeshwar, Y.C. Long, S. Lonial, B. Loos, C. Lopez-Otin, C. Lopez-Vicario, M. Lorente, P.L. Lorenzi, P. Lorincz, M. Los, M.T. Lotze, P.E. Lovat, B. Lu, B. Lu, J. Lu, Q. Lu, S.M. Lu, S. Lu, Y. Lu, F. Luciano, S. Luckhart, J.M. Lucocq, P. Ludovico, A. Lugea, N.W. Lukacs, J.J. Lum, A.H. Lund, H. Luo, J. Luo, S. Luo, C. Luparello, T. Lyons, J. Ma, Y. Ma, Y. Ma, Z. Ma, J. Machado, G.M. Machado-Santelli, F. Macian, G.C. MacIntosh, J.P. MacKeigan, K.F. Macleod, J.D. MacMicking, L.A. MacMillan-Crow, F. Madeo, M. Madesh, J. Madrigal-Matute, A. Maeda, T. Maeda, G. Maegawa, E. Maellaro, H. Maes, M. Magarinos, K. Maiese, T.K. Maiti, L. Maiuri, M.C. Maiuri, C.G. Maki, R. Malli, W. Malorni, A. Maloyan, F. Mami-Chouaib, N. Man, J.D. Mancias, E.M. Mandelkow, M.A. Mandell, A.A. Manfredi, S.N. Manie, C. Manzoni, K. Mao, Z. Mao, Z.W. Mao, P. Marambaud, A.M. Marconi, Z. Marelja, G. Marfe, M. Margeta, E. Margittai, M. Mari, F.V. Mariani, C. Marin, S. Marinelli, G. Marino, I. Markovic, R. Marquez, A.M. Martelli, S. Martens, K.R. Martin, S.J. Martin, S. Martin, M.A. 
Martin-Acebes, P. Martin-Sanz, C. Martinand-Mari, W. Martinet, J. Martinez, N. Martinez-Lopez, U. Martinez-Outschoorn, M. Martinez-Velazquez, M. Martinez-Vicente, W.K. Martins, H. Mashima, J.A. Mastrianni, G. Matarese, P. Matarrese, R. Mateo, S. Matoba, N. Matsumoto, T. Matsushita, A. Matsuura, T. Matsuzawa, M.P. Mattson, S. Matus, N. Maugeri, C. Mauvezin, A. Mayer, D.

Maysinger, G.D. Mazzolini, M.K. McBrayer, K. McCall, C. McCormick, G.M. McInerney, S.C. Mclver, S. McKenna, J.J. McMahon, I.A. McNeish, F. Mechta-Grigoriou, J.P. Medema, D.L. Medina, K. Megyeri, M. Mehrpour, J.L. Mehta, Y. Mei, U.C. Meier, A.J. Meijer, A. Melendez, G. Melino, S. Melino, E.J. de Melo, M.A. Mena, M.D. Meneghini, J.A. Menendez, R. Menezes, L. Meng, L.H. Meng, S. Meng, R. Menghini, A.S. Menko, R.F. Menna-Barreto, M.B. Menon, M.A. Meraz-Rios, G. Merla, L. Merlini, A.M. Merlot, A. Meryk, S. Meschini, J.N. Meyer, M.T. Mi, C.Y. Miao, L. Micale, S. Michaeli, C. Michiels, A.R. Migliaccio, A.S. Mihailidou, D. Mijaljica, K. Mikoshiba, E. Milan, L. MillerFleming, G.B. Mills, I.G. Mills, G. Minakaki, B.A. Minassian, X.F. Ming, F. Minibayeva, E.A. Minina, J.D. Mintern, S. Minucci, A. Miranda-Vizuete, C.H. Mitchell, S. Miyamoto, K. Miyazawa, N. Mizushima, K. Mnich, B. Mograbi, S. Mohseni, L.F. Moita, M. Molinari, M. Molinari, A.B. Moller, B. Mollereau, F. Mollinedo, M. Mongillo, M.M. Monick, S. Montagnaro, C. Montell, D.J. Moore, M.N. Moore, R. Mora-Rodriguez, P.I. Moreira, E. Morel, M.B. Morelli, S. Moreno, M.J. Morgan, A. Moris, Y. Moriyasu, J.L. Morrison, L.A. Morrison, E. Morselli, J. Moscat, P.L. Moseley, S. Mostowy, E. Motori, D. Mottet, J.C. Mottram, C.E. Moussa, V.E. Mpakou, H. Mukhtar, J.M. Mulcahy Levy, S. Muller, R. Munoz-Moreno, C. Munoz-Pinedo, C. Munz, M.E. Murphy, J.T. Murray, A. Murthy, I.U. Mysorekar, I.R. Nabi, M. Nabissi, G.A. Nader, Y. Nagahara, Y. Nagai, K. Nagata, A. Nagelkerke, P. Nagy, S.R. Naidu, S. Nair, H. Nakano, H. Nakatogawa, M. Nanjundan, G. Napolitano, N.I. Naqvi, R. Nardacci, D.P. Narendra, M. Narita, A.C. Nascimbeni, R. Natarajan, L.C. Navegantes, S.T. Nawrocki, T.Y. Nazarko, V.Y. Nazarko, T. Neill, L.M. Neri, M.G. Netea, R.T. Netea-Maier, B.M. Neves, P.A. Ney, I.P. Nezis, H.T. Nguyen, H.P. Nguyen, A.S. Nicot, H. Nilsen, P. Nilsson, M. Nishimura, I. Nishino, M. Niso-Santano, H. Niu, R.A. Nixon, V.C. Njar, T. Noda, A.A. Noegel, E.M. Nolte, E. Norberg, K.K. Norga, S.K. Noureini, S. Notomi, L. Notterpek, K. Nowikovsky, N. Nukina, T. Nurnberger, V.B. O'Donnell, T. O'Donovan, P.J. O'Dwyer, I. Oehme, C.L. Oeste, M. Ogawa, B. Ogretmen, Y. Ogura, Y.J. Oh, M. Ohmuraya, T. Ohshima, R. Ojha, K. Okamoto, T. Okazaki, F.J. Oliver, K. Ollinger, S. Olsson, D.P. Orban, P. Ordonez, I. Orhon, L. Orosz, E.J. O'Rourke, H. Orozco, A.L. Ortega, E. Ortona, L.D. Osellame, J. Oshima, S. Oshima, H.D. Osiewacz, T. Otomo, K. Otsu, J.H. Ou, T.F. Outeiro, D.Y. Ouyang, H. Ouyang, M. Overholtzer, M.A. Ozbun, P.H. Ozdinler, B. Ozpolat, C. Pacelli, P. Paganetti, G. Page, G. Pages, U. Pagnini, B. Pajak, S.C. Pak, K. Pakos-Zebrucka, N. Pakpour, Z. Palkova, F. Palladino, K. Pallauf, N. Pallet, M. Palmieri, S.R. Paludan, C. Palumbo, S. Palumbo, O. Pampliega, H. Pan, W. Pan, T. Panaretakis, A. Pandey, A. Pantazopoulou, Z. Papackova, D.L. Papademetrio, I. Papassideri, A. Papini, N. Parajuli, J. Pardo, V.V. Parekh, G. Parenti, J.I. Park, J. Park, O.K. Park, R. Parker, R. Parlato, J.B. Parys, K.R. Parzych, J.M. Pasquet, B. Pasquier, K.B. Pasumarthi, D. Patschan, C. Patterson, S. Pattingre, S. Pattison, A. Pause, H. Pavenstadt, F. Pavone, Z. Pedrozo, F.J. Pena, M.A. Penalva, M. Pende, J. Peng, F. Penna, J.M. Penninger, A. Pensalfini, S. Pepe, G.J. Pereira, P.C. Pereira, V. Perez-de la Cruz, M.E. Perez-Perez, D. Perez-Rodriguez, D. Perez-Sala, C. Perier, A. Perl, D.H. Perlmutter, I. Perrotta, S. Pervaiz, M. Pesonen, J.E. Pessin, G.J. Peters, M. Petersen, I. Petrache, B.J. Petrof, G. Petrovski, J.M. Phang, M. Piacentini, M. Pierdominici, P. Pierre, V. Pierrefite-Carle, F. Pietrocola, F.X. Pimentel-Muinos, M. Pinar, B. Pineda, R. Pinkas-Kramarski, M. Pinti, P. Pinton, B. Piperdi, J.M. Piret, L.C. Platanias, H.W. Platta, E.D. Plowey, S. Poggeler, M. Poirot, P. Polcic, A. Poletti, A.H. Poon, H. Popelka, B. Popova, I. Poprawa, S.M. Poulose, J. Poulton, S.K. Powers, T. Powers, M. Pozuelo-Rubio, K. Prak, R. Prange, M. Prescott, M. Priault, S. Prince, R.L. Proia, T. Proikas-Cezanne, H. Prokisch, V.J. Promponas, K. Przyklenk, R. Puertollano, S. Pugazhenthi, L. Puglielli, A. Pujol, J. Puyal, D. Pyeon, X. Qi, W.B. Qian, Z.H. Qin, Y. Qiu, Z. Qu, J. Quadrilatero, F. Quinn, N. Raben, H. Rabinowich, F. Radogna, M.J. Ragusa, M. Rahmani, K. Raina, S. 
Ramanadham, R. Ramesh, A. Rami, S. Randall-Demllo, F. Randow, H. Rao, V.A. Rao, B.B.

Rasmussen, T.M. Rasse, E.A. Ratovitski, P.E. Rautou, S.K. Ray, B. Razani, B.H. Reed, F. Reggiori, M.

Rehm, A.S. Reichert, T. Rein, D.J. Reiner, E. Reits, J. Ren, X. Ren, M. Renna, J.E. Reusch, J.L.

Revuelta, L. Reyes, A.R. Rezaie, R.I. Richards, D.R. Richardson, C. Richetta, M.A. Riehle, B.H. Rihn, Y.

Rikihisa, B.E. Riley, G. Rimbach, M.R. Rippo, K. Ritis, F. Rizzi, E. Rizzo, P.J. Roach, J. Robbins, M. Roberge, G. Roca, M.C. Roccheri, S. Rocha, C.M. Rodrigues, C.I. Rodriguez, S.R. de Cordoba, N. Rodriguez-Muela, J. Roelofs, V.V. Rogov, T.T. Rohn, B. Rohrer, D. Romanelli, L. Romani, P.S. Romano, M.I. Roncero, J.L. Rosa, A. Rosello, K.V. Rosen, P. Rosenstiel, M. Rost-Roszkowska, K.A. Roth, G. Roue, M. Rouis, K.M. Rouschop, D.T. Ruan, D. Ruano, D.C. Rubinsztein, E.B. Rucker, 3rd, A. Rudich, E. Rudolf, R. Rudolf, M.A. Ruegg, C. Ruiz-Roldan, A.A. Ruparelia, P. Rusmini, D.W. Russ, G.L. Russo, G. Russo, R. Russo, T.E. Rusten, V. Ryabovol, K.M. Ryan, S.W. Ryter, D.M. Sabatini, M. Sacher, C. Sachse, M.N. Sack, J. Sadoshima, P. Saftig, R. Sagi-Eisenberg, S. Sahni, P. Saikumar, T. Saito, T. Saitoh, K. Sakakura, M. Sakoh-Nakatogawa, Y. Sakuraba, M. Salazar-Roa, P. Salomoni, A.K. Saluja, P.M. Salvaterra, R. Salvioli, A. Samali, A.M. Sanchez, J.A. Sanchez-Alcazar, R. Sanchez-Prieto, M. Sandri, M.A. Sanjuan, S. Santaguida, L. Santambrogio, G. Santoni, C.N. Dos Santos, S. Saran, M. Sardiello, G. Sargent, P. Sarkar, S. Sarkar, M.R. Sarrias, M.M. Sarwal, C. Sasakawa, M. Sasaki, M. Sass, K. Sato, M. Sato, J. Satriano, N. Savaraj, S. Saveljeva, L. Schaefer, U.E. Schaible, M. Scharl, H.M. Schatzl, R. Schekman, W. Scheper, A. Schiavi, H.M. Schipper, H. Schmeisser, J. Schmidt, I. Schmitz, B.E. Schneider, E.M. Schneider, J.L. Schneider, E.A. Schon, M.J. Schonenberger, A.H. Schonthal, D.F. Schorderet, B. Schroder, S. Schuck, R.J. Schulze, M. Schwarten, T.L. Schwarz, S. Sciarretta, K. Scotto, A.I. Scovassi, R.A. Screaton, M. Screen, H. Seca, S. Sedej, L. Segatori, N. Segev, P.O. Seglen, J.M. Segui-Simarro, J. Segura-Aguilar, E. Seki, C. Sell, I. Seiliez, C.F. Semenkovich, G.L. Semenza, U. Sen, A.L. Serra, A. Serrano-Puebla, H. Sesaki, T. Setoguchi, C. Settembre, J.J. Shacka, A.N. Shajahan-Haq, I.M. Shapiro, S. Sharma, H. She, C.K. Shen, C.C. Shen, H.M. Shen, S. Shen, W. Shen, R. Sheng, X. Sheng, Z.H. Sheng, T.G. Shepherd, J. Shi, Q. Shi, Q. Shi, Y. Shi, S. Shibutani, K. Shibuya, Y. Shidoji, J.J. Shieh, C.M. Shih, Y. Shimada, S. Shimizu, D.W. Shin, M.L. Shinohara, M. Shintani, T. Shintani, T. Shioi, K. Shirabe, R. Shiri-Sverdlov, O. Shirihai, G.C. Shore, C.W. Shu, D. Shukla, A.A. Sibirny, V. Sica, C.J. Sigurdson, E.M. Sigurdsson, P.S. Sijwali, B. Sikorska, W.A. Silveira, S. Silvente-Poirot, G.A. Silverman, J. Simak, T. Simmet, A.K. Simon, H.U. Simon, C. Simone, M. Simons, A. Simonsen, R. Singh, S.V. Singh, S.K. Singh, D. Sinha, S. Sinha, F.A. Sinicrope, A. Sirko, K. Sirohi, B.J. Sishi, A. Sittler, P.M. Siu, E. Sivridis, A. Skwarska, R. Slack, I. Slaninova, N. Slavov, S.S. Smaili, K.S. Smalley, D.R. Smith, S.J. Soenen, S.A. Soleimanpour, A. Solhaug, K. Somasundaram, J.H. Son, A. Sonawane, C. Song, F. Song, H.K. Song, J.X. Song, W. Song, K.Y. Soo, A.K. Sood, T.W. Soong, V. Soontornniyomkij, M. Sorice, F. Sotgia, D.R. Soto-Pantoja, A. Sotthibundhu, M.J. Sousa, H.P. Spaink, P.N. Span, A. Spang, J.D. Sparks, P.G. Speck, S.A. Spector, C.D. Spies, W. Springer, D.S. Clair, A. Stacchiotti, B. Staels, M.T. Stang, D.T. Starczynowski, P. Starokadomskyy, C. Steegborn, J.W. Steele, L. Stefanis, J. Steffan, C.M. Stellrecht, H. Stenmark, T.M. Stepkowski, S.T. Stern, C. Stevens, B.R. Stockwell, V. Stoka, Z. Storchova, B. Stork, V. Stratoulias, D.J. Stravopodis, P. Strnad, A.M. Strohecker, A.L. Strom, P. Stromhaug, J. Stulik, Y.X. Su, Z. Su, C.S. Subauste, S. Subramaniam, C.M. Sue, S.W. Suh, X. Sui, S. Sukseree, D. Sulzer, F.L. Sun, J. Sun, J. Sun, S.Y. Sun, Y. Sun, Y. Sun, Y. Sun, V. Sundaramoorthy, J. Sung, H. Suzuki, K. Suzuki, N. Suzuki, T. Suzuki, Y.J. Suzuki, M.S. Swanson, C. Swanton, K. Sward, G. Swarup, S.T. Sweeney, P.W. Sylvester, Z. Szatmari, E. Szegezdi, P.W. Szlosarek, H. Taegtmeyer, M. Tafani, E. Taillebourg, S.W. Tait, K. Takacs-Vellai, Y. Takahashi, S. Takats, G. Takemura, N. Takigawa, N.J. Talbot, E. Tamagno, J. Tamburini, C.P. Tan, L. Tan, M.L. Tan, M. Tan, Y.J. Tan, K. Tanaka, M. Tanaka, D. Tang, D. Tang, G. Tang, I. Tanida, K. Tanji, B.A. Tannous, J.A. Tapia, I. Tasset-Cuevas, M. Tatar, I. Tavassoly, N. Tavernarakis, A. Taylor, G.S. Taylor, G.A. Taylor, J.P. Taylor, M.J. Taylor, E.V. Tchetina, A.R. Tee, F. Teixeira-Clerc, S. Telang, T. Tencomnao, B.B. Teng, R.J. Teng, F. Terro, G. Tettamanti, A.L. Theiss, A.E. Theron, K.J. Thomas, M.P. Thome, 
P.G. Thomes, A. Thorburn, J. Thorner, T. Thum, M. Thumm, T.L. Thurston, L. Tian, A. Till, J.P. Ting, V.I. Titorenko, L. Toker, S. Toldo, S.A. Tooze, I. Topisirovic, M.L. Torgersen, L. Torosantucci, A. Torriglia, M.R. Torrisi, C. Tournier, R. Towns, V. Trajkovic, L.H. Travassos, G. Triola, D.N. Tripathi, D. Trisciuoglio, R. Troncoso, I.P. Trougakos, A.C. Truttmann, K.J. Tsai, M.P. Tschan, Y.H. Tseng, T. Tsukuba, A. Tsung, A.S. Tsvetkov, S. Tu, H.Y. Tuan, M. Tucci, D.A. Tumbarello, B. Turk, V. Turk, R.F. Turner, A.A. Tveita, S.C. Tyagi, M. Ubukata, Y. Uchiyama, A. Udelnow, T. Ueno, M. Umekawa, R. Umemiya-Shirafuji, B.R. Underwood, C. Ungermann, R.P. Ureshino, R. Ushioda, V.N. Uversky, N.L. Uzcategui, T. Vaccari, M.I. Vaccaro, L. Vachova, H. Vakifahmetoglu-Norberg, R. Valdor, E.M. Valente, F. Vallette, A.M. Valverde, G. Van den Berghe, L. Van Den Bosch, G.R. van den Brink, F.G. van der Goot, I.J. van der Klei, L.J. van der Laan, W.G. van Doorn, M. van Egmond, K.L. van Golen, L. Van Kaer, M. van Lookeren Campagne, P. Vandenabeele, W. Vandenberghe, I. Vanhorebeek, I. Varela-Nieto, M.H. Vasconcelos, R. Vasko, D.G. Vavvas, I. Vega-Naredo, G. Velasco, A.D. Velentzas, P.D. Velentzas, T. Vellai, E. Vellenga, M.H. Vendelbo, K. Venkatachalam, N. Ventura, S. Ventura, P.S. Veras, M. Verdier, B.G. Vertessy, A. Viale, M. Vidal, H.L. Vieira, R.D. Vierstra, N. Vigneswaran, N. Vij, M. Vila, M. Villar, V.H. Villar, J. Villarroya, C. Vindis, G. Viola, M.T. Viscomi, G. Vitale, D.T. Vogl, O.V. Voitsekhovskaja, C. von Haefen, K. von Schwarzenberg, D.E. Voth, V. Vouret-Craviari, K. Vuori, J.M. Vyas, C. Waeber, C.L. Walker, M.J. Walker, J. Walter, L. Wan, X. Wan, B. Wang, C. Wang, C.Y. Wang, C. Wang, C. Wang, C. Wang, D. Wang, F. Wang, F. Wang, G. Wang, H.J. Wang, H. Wang, H.G. Wang, H. Wang, H.D. Wang, J. Wang, J. Wang, M. Wang, M.Q. Wang, P.Y. Wang, P. Wang, R.C. Wang, S. Wang, T.F. Wang, X. Wang, X.J. Wang, X.W. Wang, X. Wang, X. Wang, Y. Wang, Y. Wang, Y. Wang, Y.J. Wang, Y. Wang, Y. Wang, Y.T. Wang, Y. Wang, Z.N. Wang, P. Wappner, C. Ward, D.M. Ward, G. Warnes, H. Watada, Y. Watanabe, K. Watase, T.E. Weaver, C.D. Weekes, J. Wei, T. Weide, C.C. Weihl, G. Weindl, S.N. Weis, L. Wen, X. Wen, Y. Wen, B.

Westermann, C.M. Weyand, A.R. White, E. White, J.L. Whitton, A.J. Whitworth, J. Wiels, F. Wild, M.E. Wildenberg, T. Wileman, D.S. Wilkinson, S. Wilkinson, D. Willbold, C. Williams, K. Williams, P.R. Williamson, K.F. Winklhofer, S.S. Witkin, S.E. Wohlgemuth, T. Wollert, E.J. Wolvetang, E. Wong, G.W. Wong, R.W. Wong, V.K. Wong, E.A. Woodcock, K.L. Wright, C. Wu, D. Wu, G.S. Wu, J. Wu, J. Wu, M. Wu, M. Wu, S. Wu, W.K. Wu, Y. Wu, Z. Wu, C.P. Xavier, R.J. Xavier, G.X. Xia, T. Xia, W. Xia, Y. Xia, H. Xiao, J. Xiao, S. Xiao, W. Xiao, C.M. Xie, Z. Xie, Z. Xie, M. Xilouri, Y. Xiong, C. Xu, C. Xu, F. Xu, H. Xu, H. Xu, J. Xu, J. Xu, J. Xu, L. Xu, X. Xu, Y. Xu, Y. Xu, Z.X. Xu, Z. Xu, Y. Xue, T. Yamada, A. Yamamoto, K. Yamanaka, S. Yamashina, S. Yamashiro, B. Yan, B. Yan, X. Yan, Z. Yan, Y. Yanagi, D.S. Yang, J.M. Yang, L. Yang, M. Yang, P.M. Yang, P. Yang, Q. Yang, W. Yang, W.Y. Yang, X. Yang, Y. Yang, Y. Yang, Z. Yang, Z. Yang, M.C. Yao, P.J. Yao, X. Yao, Z. Yao, Z. Yao, L.S. Yasui, M. Ye, B. Yedvobnick, B. Yeganeh, E.S. Yeh, P.L. Yeyati, F. Yi, L. Yi, X.M. Yin, C.K. Yip, Y.M. Yoo, Y.H. Yoo, S.Y. Yoon, K. Yoshida, T. Yoshimori, K.H. Young, H. Yu, J.J. Yu, J.T. Yu, J. Yu, L. Yu, W.H. Yu, X.F. Yu, Z. Yu, J. Yuan, Z.M. Yuan, B.Y. Yue, J. Yue, Z. Yue, D.N. Zacks, E. Zacksenhaus, N. Zaffaroni, T. Zaglia, Z. Zakeri, V. Zecchini, J. Zeng, M. Zeng, Q. Zeng, A.S. Zervos, D.D. Zhang, F. Zhang, G. Zhang, G.C. Zhang, H. Zhang, H. Zhang, H. Zhang, H. Zhang, J. Zhang, J. Zhang, J. Zhang, J. Zhang, J.P. Zhang, L. Zhang, L. Zhang, L. Zhang, L. Zhang, M.Y. Zhang, X. Zhang, X.D. Zhang, Y. Zhang, Y. Zhang, Y. Zhang, Y. Zhang, Y. Zhang, M. Zhao, W.L. Zhao, X. Zhao, Y.G. Zhao, Y. Zhao, Y. Zhao, Y.X. Zhao, Z. Zhao, Z.J. Zhao, D. Zheng, X.L. Zheng, X. Zheng, B. Zhivotovsky, Q. Zhong, G.Z. Zhou, G. Zhou, H. Zhou, S.F. Zhou, X.J. Zhou, H. Zhu, H. Zhu, W.G. Zhu, W. Zhu, X.F. Zhu, Y. Zhu, S.M. Zhuang, X. Zhuang, E. Ziparo, C.E. Zois, T. Zoladek, W.X. Zong, A. Zorzano, S.M. Zughaier, Guidelines for the use and interpretation of assays for monitoring autophagy (3rd edition), Autophagy, 12 (2016) 1-222. [88] D. Denton, S. Kumar, Autophagy-dependent cell death, Cell Death Differ, 26 (2019) 605-616. [89] L. Dini, V. Inguscio, B. Tenuzzo, E. Panzarini, Rose bengal acetate photodynamic therapyinduced autophagy, Cancer Biol Ther, 10 (2010) 1048-1055. 
[90] D. Kessel, M.G. Vicente, J.J. Reiners, Jr., Initiation of apoptosis and autophagy by photodynamic therapy, Lasers Surg Med, 38 (2006) 482-488.

[91] D. Kessel, M.G. Vicente, J.J. Reiners, Jr., Initiation of apoptosis and autophagy by photodynamic therapy, Autophagy, 2 (2006) 289-290.

[92] M. Dewaele, W. Martinet, N. Rubio, T. Verfaillie, P.A. de Witte, J. Piette, P. Agostinis, Autophagy pathways activated in response to PDT contribute to cell resistance against ROS damage, J Cell Mol Med, 15 (2011) 1402-1414.

[93] D. Kessel, J.J. Reiners, Jr., Apoptosis and autophagy after mitochondrial or endoplasmic reticulum photodamage, Photochem Photobiol, 83 (2007) 1024-1028.

[94] M. Andrzejak, M. Price, D.H. Kessel, Apoptotic and autophagic responses to photodynamic therapy in 1c1c7 murine hepatoma cells, Autophagy, 7 (2011) 979-984.

[95] D.H. Kessel, M. Price, J.J. Reiners, Jr., ATG7 deficiency suppresses apoptosis and cell death induced by lysosomal photodamage, Autophagy, 8 (2012) 1333-1341.

[96] L.C. Gomes-da-Silva, A.J. Jimenez, A. Sauvat, W. Xie, S. Souquere, S. Divoux, M. Storch, B. Sveinbjornsson, O. Rekdal, L.G. Arnaut, O. Kepp, G. Kroemer, F. Perez, Recruitment of LC3 to damaged Golgi apparatus, Cell Death Differ, (2018).

[97] M. Niso-Santano, S.A. Malik, F. Pietrocola, J.M. Bravo-San Pedro, G. Marino, V. Cianfanelli, A. Ben-Younes, R. Troncoso, M. Markaki, V. Sica, V. Izzo, K. Chaba, C. Bauvy, N. Dupont, O. Kepp, P. Rockenfeller, H. Wolinski, F. Madeo, S. Lavandero, P. Codogno, F. Harper, G. Pierron, N.

Tavernarakis, F. Cecconi, M.C. Maiuri, L. Galluzzi, G. Kroemer, Unsaturated fatty acids induce noncanonical autophagy, EMBO J, 34 (2015) 1025-1041.

[98] S. Zhang, Y. Wang, W. Xie, E.N.W. Howe, N. Busschaert, A. Sauvat, M. Leduc, L.C. Gomes-daSilva, G. Chen, I. Martins, X. Deng, L. Maiuri, O. Kepp, T. Soussi, P.A. Gale, N. Zamzami, G. Kroemer, Squaramide-based synthetic chloride transporters activate TFEB but block autophagic flux, Cell Death Dis, 10 (2019) 242.

[99] H. Yang, Y. Ma, G. Chen, H. Zhou, T. Yamazaki, C. Klein, F. Pietrocola, E. Vacchelli, S. Souquere, A. Sauvat, L. Zitvogel, O. Kepp, G. Kroemer, Contribution of RIP3 and MLKL to immunogenic cell death signaling in cancer chemotherapy, Oncoimmunology, 5 (2016) e1149673.

[100] T.L. Aaes, A. Kaczmarek, T. Delvaeye, B. De Craene, S. De Koker, L. Heyndrickx, I. Delrue, J. Taminau, B. Wiernicki, P. De Groote, A.D. Garg, L. Leybaert, J. Grooten, M.J. Bertrand, P. Agostinis, G. Berx, W. Declercq, P. Vandenabeele, D.V. Krysko, Vaccination with Necroptotic Cancer Cells Induces Efficient Anti-tumor Immunity, Cell Rep, 15 (2016) 274-287.

[101] G. Kroemer, L. Galluzzi, O. Kepp, L. Zitvogel, Immunogenic cell death in cancer therapy, Annu Rev Immunol, 31 (2013) 51-72.

[102] A.D. Garg, D. Nowis, J. Golab, P. Vandenabeele, D.V. Krysko, P. Agostinis, Immunogenic cell death, DAMPs and anticancer therapeutics: an emerging amalgamation, Biochim Biophys Acta, 1805 (2010) 53-71.

[103] T. Panaretakis, O. Kepp, U. Brockmeier, A. Tesniere, A.C. Bjorklund, D.C. Chapman, M. Durchschlag, N. Joza, G. Pierron, P. van Endert, J. Yuan, L. Zitvogel, F. Madeo, D.B. Williams, G. Kroemer, Mechanisms of pre-apoptotic calreticulin exposure in immunogenic cell death, EMBO J, 28 (2009) 578-590.

[104] M. Obeid, A. Tesniere, F. Ghiringhelli, G.M. Fimia, L. Apetoh, J.L. Perfettini, M. Castedo, G. Mignot, T. Panaretakis, N. Casares, D. Metivier, N. Larochette, P. van Endert, F. Ciccosanti, M. Piacentini, L. Zitvogel, G. Kroemer, Calreticulin exposure dictates the immunogenicity of cancer cell death, Nat Med, 13 (2007) 54-61.

[105] L. Bezu, A. Sauvat, J. Humeau, L.C. Gomes-da-Silva, K. Iribarren, S. Forveille, P. Garcia, L. Zhao, P. Liu, L. Zitvogel, L. Senovilla, O. Kepp, G. Kroemer, elF2alpha phosphorylation is pathognomonic for immunogenic cell death, Cell Death Differ, 25 (2018) 1375-1393. 
[106] L. Bezu, A. Sauvat, J. Humeau, M. Leduc, O. Kepp, G. Kroemer, elF2alpha phosphorylation: A hallmark of immunogenic cell death, Oncoimmunology, 7 (2018) e1431089.

[107] J. Fucikova, E. Becht, K. Iribarren, J. Goc, R. Remark, D. Damotte, M. Alifano, P. Devi, J. Biton, C. Germain, A. Lupo, W.H. Fridman, M.C. Dieu-Nosjean, G. Kroemer, C. Sautes-Fridman, I. Cremer, Calreticulin Expression in Human Non-Small Cell Lung Cancers Correlates with Increased Accumulation of Antitumor Immune Cells and Favorable Prognosis, Cancer Res, 76 (2016) 17461756.

[108] J. Fucikova, I. Truxova, M. Hensler, E. Becht, L. Kasikova, I. Moserova, S. Vosahlikova, J. Klouckova, S.E. Church, I. Cremer, O. Kepp, G. Kroemer, L. Galluzzi, C. Salek, R. Spisek, Calreticulin exposure by malignant blasts correlates with robust anticancer immunity and improved clinical outcome in AML patients, Blood, 128 (2016) 3113-3124.

[109] L. Guo, Y. Chi, J. Xue, L. Ma, Z. Shao, J. Wu, Phosphorylated elF2alpha predicts disease-free survival in triple-negative breast cancer patients, Sci Rep, 7 (2017) 44674.

[110] M. Michaud, I. Martins, A.Q. Sukkurwala, S. Adjemian, Y. Ma, P. Pellegatti, S. Shen, O. Kepp, M. Scoazec, G. Mignot, S. Rello-Varona, M. Tailler, L. Menger, E. Vacchelli, L. Galluzzi, F. Ghiringhelli, F. di Virgilio, L. Zitvogel, G. Kroemer, Autophagy-dependent anticancer immune responses induced by chemotherapeutic agents in mice, Science, 334 (2011) 1573-1577.

[111] A.D. Garg, A.M. Dudek, G.B. Ferreira, T. Verfaillie, P. Vandenabeele, D.V. Krysko, C. Mathieu, P. Agostinis, ROS-induced autophagy in cancer cells assists in evasion from determinants of immunogenic cell death, Autophagy, 9 (2013) 1292-1307.

[112] E. Vacchelli, Y. Ma, E.E. Baracco, A. Sistigu, D.P. Enot, F. Pietrocola, H. Yang, S. Adjemian, K. Chaba, M. Semeraro, M. Signore, A. De Ninno, V. Lucarini, F. Peschiaroli, L. Businaro, A. Gerardino, G. Manic, T. Ulas, P. Gunther, J.L. Schultze, O. Kepp, G. Stoll, C. Lefebvre, C. Mulot, F. Castoldi, S. Rusakiewicz, S. Ladoire, L. Apetoh, J.M. Bravo-San Pedro, M. Lucattelli, C. Delarasse, V. Boige, M. Ducreux, S. Delaloge, C. Borg, F. Andre, G. Schiavoni, I. Vitale, P. Laurent-Puig, F. Mattei, L. Zitvogel, G. Kroemer, Chemotherapy-induced antitumor immunity requires formyl peptide receptor 1, Science (New York, N.Y.), 350 (2015) 972-978.

[113] E. Vacchelli, D.P. Enot, F. Pietrocola, L. Zitvogel, G. Kroemer, Impact of Pattern Recognition Receptors on the Prognosis of Breast Cancer Patients Undergoing Adjuvant Chemotherapy, Cancer Research, 76 (2016) 3122.

[114] A.Q. Sukkurwala, S. Adjemian, L. Senovilla, M. Michaud, S. Spaggiari, E. Vacchelli, E.E. Baracco, L. Galluzzi, L. Zitvogel, O. Kepp, G. Kroemer, Screening of novel immunogenic cell death inducers within the NCl Mechanistic Diversity Set, Oncoimmunology, 3 (2014) e28473.

[115] I. Martins, O. Kepp, F. Schlemmer, S. Adjemian, M. Tailler, S. Shen, M. Michaud, L. Menger, A. Gdoura, N. Tajeddine, A. Tesniere, L. Zitvogel, G. Kroemer, Restoration of the immunogenicity of cisplatin-induced cancer cell death by endoplasmic reticulum stress, Oncogene, 30 (2011) 11471158.

[116] W.J. de Vree, M.C. Essers, H.S. de Bruijn, W.M. Star, J.F. Koster, W. Sluiter, Evidence for an important role of neutrophils in the efficacy of photodynamic therapy in vivo, Cancer Res, 56 (1996) 2908-2911.

[117] S.O. Gollnick, X. Liu, B. Owczarczak, D.A. Musser, B.W. Henderson, Altered expression of interleukin 6 and interleukin 10 as a result of photodynamic therapy in vivo, Cancer Res, 57 (1997) 3904-3909.

[118] A.D. Garg, D.V. Krysko, P. Vandenabeele, P. Agostinis, The emergence of phox-ER stress induced immunogenic apoptosis, Oncoimmunology, 1 (2012) 786-788.

[119] L. Galluzzi, O. Kepp, G. Kroemer, Enlightening the impact of immunogenic cell death in photodynamic cancer therapy, EMBO J, 31 (2012) 1055-1057. 
[120] A.D. Garg, D.V. Krysko, T. Verfaillie, A. Kaczmarek, G.B. Ferreira, T. Marysael, N. Rubio, M. Firczuk, C. Mathieu, A.J. Roebroek, W. Annaert, J. Golab, P. de Witte, P. Vandenabeele, P. Agostinis, A novel pathway combining calreticulin exposure and ATP secretion in immunogenic cancer cell death, EMBO J, 31 (2012) 1062-1079.

[121] A.D. Garg, D.V. Krysko, P. Vandenabeele, P. Agostinis, Hypericin-based photodynamic therapy induces surface exposure of damage-associated molecular patterns like HSP70 and calreticulin, Cancer Immunol Immunother, 61 (2012) 215-221.

[122] A.D. Garg, L. Vandenberk, C. Koks, T. Verschuere, L. Boon, S.W. Van Gool, P. Agostinis, Dendritic cell vaccines based on immunogenic cell death elicit danger signals and T cell-driven rejection of high-grade glioma, Science translational medicine, 8 (2016) 328ra327.

[123] E. Panzarini, V. Inguscio, G.M. Fimia, L. Dini, Rose Bengal acetate photodynamic therapy (RBAc-PDT) induces exposure and release of Damage-Associated Molecular Patterns (DAMPs) in human HeLa cells, PloS one, 9 (2014) e105778-e105778.

[124] J. Qin, N. Kunda, G. Qiao, J.F. Calata, K. Pardiwala, B.S. Prabhakar, A.V. Maker, Colon cancer cell treatment with rose bengal generates a protective immune response via immunogenic cell death, Cell death \& disease, 8 (2017) e2584.

[125] J. Ji, Z. Fan, F. Zhou, X. Wang, L. Shi, H. Zhang, P. Wang, D. Yang, L. Zhang, W.R. Chen, X. Wang, Improvement of DC vaccine with ALA-PDT induced immunogenic apoptotic cells for skin squamous cell carcinoma, Oncotarget, 6 (2015) 17135-17146.

[126] X. Wang, J. Ji, H. Zhang, Z. Fan, L. Zhang, L. Shi, F. Zhou, W.R. Chen, H. Wang, X. Wang, Stimulation of dendritic cells by DAMPs in ALA-PDT treated SCC tumor cells, Oncotarget, 6 (2015) 44688-44702.

[127] M. Korbelik, J. Sun, I. Cecic, Photodynamic therapy-induced cell surface expression and release of heat shock proteins: relevance for tumor response, Cancer Res, 65 (2005) 1018-1026. [128] F. Zhou, D. Xing, W. Chen, Dynamics and mechanism of HSP70 translocation induced by photodynamic therapy treatment, Place Published, 2008.

[129] M. Korbelik, W. Zhang, S. Merchant, Involvement of damage-associated molecular patterns in tumor response to photodynamic therapy: surface expression of calreticulin and high-mobility group box-1 release, Cancer immunology, immunotherapy : Cll, 60 (2011) 1431-1437.

[130] M. Tanaka, H. Kataoka, S. Yano, T. Sawada, H. Akashi, M. Inoue, S. Suzuki, Y. Inagaki, N. Hayashi, H. Nishie, T. Shimura, T. Mizoshita, Y. Mori, E. Kubota, S. Tanida, S. Takahashi, T. Joh, Immunogenic cell death due to a new photodynamic therapy (PDT) with glycoconjugated chlorin (G-chlorin), Oncotarget, 7 (2016) 47242-47251.

[131] S. Mitra, B.R. Giesselman, F.J. De Jesús-Andino, T.H. Foster, Tumor response to mTHPCmediated photodynamic therapy exhibits strong correlation with extracellular release of HSP70, Lasers in surgery and medicine, 43 (2011) 632-643.

[132] J. Humeau, S. Levesque, G. Kroemer, J.G. Pol, Gold Standard Assessment of Immunogenic Cell Death in Oncological Mouse Models, Methods Mol Biol, 1884 (2019) 297-315.

[133] S.O. Gollnick, L. Vaughan, B.W. Henderson, Generation of effective antitumor vaccines using photodynamic therapy, Cancer Res, 62 (2002) 1604-1608.

[134] M. Korbelik, J. Sun, Photodynamic therapy-generated vaccine for cancer therapy, Cancer Immunol Immunother, 55 (2006) 900-909.

[135] M. Korbelik, S. Merchant, Photodynamic therapy-generated cancer vaccine elicits acute phase and hormonal response in treated mice, Cancer Immunol Immunother, 61 (2012) 13871394.

[136] M. Korbelik, B. Stott, J. Sun, Photodynamic therapy-generated vaccines: relevance of tumour cell death expression, Br J Cancer, 97 (2007) 1381-1387. 
[137] M. Korbelik, S. Merchant, N. Huang, Exploitation of immune response-eliciting properties of hypocrellin photosensitizer SL052-based photodynamic therapy for eradication of malignant tumors, Photochem Photobiol, 85 (2009) 1418-1424.

[138] H. Zhang, W. Ma, Y. Li, Generation of effective vaccines against liver cancer by using photodynamic therapy, Lasers Med Sci, 24 (2009) 549-552.

[139] M. Korbelik, Cancer vaccines generated by photodynamic therapy, Photochem Photobiol Sci, 10 (2011) 664-669.

[140] L. Galluzzi, L. Senovilla, E. Vacchelli, A. Eggermont, W.H. Fridman, J. Galon, C. SautesFridman, E. Tartour, L. Zitvogel, G. Kroemer, Trial watch: Dendritic cell-based interventions for cancer therapy, Oncoimmunology, 1 (2012) 1111-1134.

[141] A.D. Garg, M. Vara Perez, M. Schaaf, P. Agostinis, L. Zitvogel, G. Kroemer, L. Galluzzi, Trial watch: Dendritic cell-based anticancer immunotherapy, Oncoimmunology, 6 (2017) e1328341.

[142] N.C. Jung, H.J. Kim, M.S. Kang, J.H. Lee, J.Y. Song, H.G. Seo, Y.S. Bae, D.S. Lim, Photodynamic therapy-mediated DC immunotherapy is highly effective for the inhibition of established solid tumors, Cancer Lett, 324 (2012) 58-65.

[143] J. Ji, Y. Zhang, W.R. Chen, X. Wang, DC vaccine generated by ALA-PDT-induced immunogenic apoptotic cells for skin squamous cell carcinoma, Oncoimmunology, 5 (2016) e1072674.

[144] Y. Zheng, G. Yin, V. Le, A. Zhang, S. Chen, X. Liang, J. Liu, Photodynamic-therapy Activates Immune Response by disrupting Immunity Homeostasis of Tumor Cells, which Generates Vaccine for Cancer Therapy, Int J Biol Sci, 12 (2016) 120-132.

[145] A.P. Castano, P. Mroz, M.R. Hamblin, Photodynamic therapy and anti-tumour immunity, Nat Rev Cancer, 6 (2006) 535-545.

[146] L.H. Wei, H. Baumann, E. Tracy, Y. Wang, A. Hutson, S. Rose-John, B.W. Henderson, Interleukin-6 trans signalling enhances photodynamic therapy by modulating cell cycling, British journal of cancer, 97 (2007) 1513-1522.

[147] P.C. Kousis, B.W. Henderson, P.G. Maier, S.O. Gollnick, Photodynamic therapy enhancement of antitumor immunity is regulated by neutrophils, Cancer Res, 67 (2007) 10501-10510.

[148] I. Cecic, M. Korbelik, Mediators of peripheral blood neutrophilia induced by photodynamic therapy of solid tumors, Cancer letters, 183 (2002) 43-51.

[149] J. Sun, I. Cecic, C.S. Parkins, M. Korbelik, Neutrophils as inflammatory and immune effectors in photodynamic therapy-treated mouse SCCVII tumours, Photochemical \& photobiological sciences : Official journal of the European Photochemistry Association and the European Society for Photobiology, 1 (2002) 690-695.

[150] A.D. Garg, L. Vandenberk, S. Fang, T. Fasche, S. Van Eygen, J. Maes, M. Van Woensel, C. Koks, N. Vanthillo, N. Graf, P. de Witte, S. Van Gool, P. Salven, P. Agostinis, Pathogen response-like recruitment and activation of neutrophils by sterile immunogenic dying cells drives neutrophilmediated residual cell killing, Cell death and differentiation, 24 (2017) 832-843.

[151] D. Preise, R. Oren, I. Glinert, V. Kalchenko, S. Jung, A. Scherz, Y. Salomon, Systemic antitumor protection by vascular-targeted photodynamic therapy involves cellular and humoral immunity, Cancer Immunol Immunother, 58 (2009) 71-84.

[152] P.S. Thong, K.W. Ong, N.S. Goh, K.W. Kho, V. Manivasager, R. Bhuvaneswari, M. Olivo, K.C. Soo, Photodynamic-therapy-activated immune response against distant untreated tumours in recurrent angiosarcoma, The Lancet. Oncology, 8 (2007) 950-952.

[153] J.W. Kleinovink, M.F. Fransen, C.W. Lowik, F. Ossendorp, Photodynamic-Immune Checkpoint Therapy Eradicates Local and Distant Tumors by CD8(+) T Cells, Cancer immunology research, 5 (2017) 832-838.

[154] M.J. O'Shaughnessy, K.S. Murray, S.P. La Rosa, S. Budhu, T. Merghoub, A. Somma, S. Monette, K. Kim, R.B. Corradi, A. Scherz, J.A. Coleman, Systemic Antitumor Immunity by PD-1/PD- 
L1 Inhibition Is Potentiated by Vascular-Targeted Photodynamic Therapy of Primary Tumors, Clin Cancer Res, 24 (2018) 592-599.

[155] Y.I. Miller, S.H. Choi, P. Wiesner, L. Fang, R. Harkewicz, K. Hartvigsen, A. Boullier, A. Gonen, C.J. Diehl, X. Que, E. Montano, P.X. Shaw, S. Tsimikas, C.J. Binder, J.L. Witztum, Oxidation-specific epitopes are danger-associated molecular patterns recognized by pattern recognition receptors of innate immunity, Circ Res, 108 (2011) 235-248. 